\title{
Homeostasis Meets Motivation in the Battle to Control Food Intake
}

\author{
(1)Carrie R. Ferrario, ${ }^{1 \star}$ Gwenaël Labouèbe, ${ }^{2 \star}$ Shuai Liu, ${ }^{3 \star}$ Edward H. Nieh, ${ }^{4 *}$ Vanessa H. Routh, ${ }^{5 *}$ Shengjin Xu, ${ }^{6 *}$ \\ and ${ }^{\circ}$ Eoin C. O'Connor ${ }^{7}$ \\ ${ }^{1}$ University of Michigan Medical School, Department of Pharmacology, Ann Arbor, Michigan 48109-5632, ${ }^{2}$ University of Lausanne, Center for Integrative \\ Genomics, Lausanne, CH1015, Switzerland, ${ }^{3}$ University of Calgary, Calgary, Alberta T2N 4N1, Canada, ${ }^{4}$ Picower Institute for Learning and Memory, \\ Department of Brain and Cognitive Sciences, Massachusetts Institute of Technology, Cambridge, Massachusetts 02139, ${ }^{5}$ Rutgers New Jersey Medical \\ School, Newark, New Jersey 07103, ${ }^{\top} J a n e l i a$ Research Campus, Howard Hughes Medical Institute, Ashburn, Virginia 20147, and University of Geneva, \\ Department of Basic Neuroscience, Geneva, CH1211, Switzerland
}

Signals of energy homeostasis interact closely with neural circuits of motivation to control food intake. An emerging hypothesis is that the transition to maladaptive feeding behavior seen in eating disorders or obesity may arise from dysregulation of these interactions. Focusing on key brain regions involved in the control of food intake (ventral tegmental area, striatum, hypothalamus, and thalamus), we describe how activity of specific cell types embedded within these regions can influence distinct components of motivated feeding behavior. We review how signals of energy homeostasis interact with these regions to influence motivated behavioral output and present evidence that experience-dependent neural adaptations in key feeding circuits may represent cellular correlates of impaired food intake control. Future research into mechanisms that restore the balance of control between signals of homeostasis and motivated feeding behavior may inspire new treatment options for eating disorders and obesity.

Key words: accumbens; AGRP; arculate nucleus; dieting; dopamine; ghrelin; glucose; insulin; leptin; orexin; paraventricular thalamic nucleus; POMC; reward

\section{Introduction}

Since 1980, the worldwide prevalence of overweight (body mass index $\geq 25$ ) and obesity (body mass index $\geq 30$ ) has more than doubled, affecting men, women and children in both developed and developing countries (World Health Organisation, 2016). An increase in body mass index represents a major risk factor for many non-communicable diseases, including cardiovascular disease, some forms of cancer, and Alzheimer's disease (Fadel et al., 2013; O'Neill and O'Driscoll, 2015; Arnold et al., 2016). Eating disorders, such as anorexia nervosa, although relatively rare among the general population, are associated with elevated mortality risks (Papadopoulos et al., 2009; Smink et al., 2012). A multitude of both environmental and genetic factors influence the prevalence of obesity and eating disorders (Bakalar et al., 2015; Hruby et al., 2016), yet altered food intake is a common symptom (American Psychiatric Association, 2015; World

\footnotetext{
Received July 23, 2016; revised Aug. 30, 2016; accepted Sept. 5, 2016.

C.R.F. was supported by National Institutes of Health Research Project Grant R01DK106188. E.H.N. was supported by the National Science Foundation Graduate Research Fellowship NSF GRFP, Integrative Neuronal Systems Training Fellowship T32 GM007484, and Training Program in the Neurobiology of Learning and Memory. V.H.R. was supported by American Heart Association Grant in Aid 14GRNT20380639. We thank Sarah Thoeni, Ruud Van Zessen, and Scott Sternson for comments on the manuscript.

The authors declare no competing financial interests.

${ }^{*}$ C.R.F., G.L., S.L., E.H.N., V.H.R., and S.X. contributed equally to this work.

Correspondence should be addressed to Dr. Eoin C. O'Connor, University of Geneva, Department of Basic Neuroscience, CMU 1, Rue Michel Servet, Geneva, CH1211, Switzerland. E-mail: eoin.oconnor@unige.ch.

DOI:10.1523/JNEUROSCI.2338-16.2016

Copyright $\odot 2016$ the authors $\quad 0270-6474 / 16 / 3611469-13 \$ 15.00 / 0$
}

Health Organisation, 2016). Thus, understanding mechanisms that mediate the regulation of food intake will likely aid in the identification of novel treatment options for eating disorders and obesity.

Food intake is determined by a rich interplay of circulating signals of energy homeostasis with brain circuits encoding the diverse behavioral repertoire required to acquire and consume food (Berthoud, 2004; Kelley et al., 2005; Fulton, 2010; Narayanan et al., 2010; Sternson, 2013). For example, the adiposederived hormones insulin and leptin act on brain circuits to suppress feeding and promote energy expenditure in response to energy surfeit (Chen et al., 1975; Woods et al., 1979; Halaas et al., 1995; Pelleymounter et al., 1995; Chua et al., 1996; Obici et al., 2002). Short-term homeostatic signals, such as ghrelin and cholecystokinin, are produced in the gastrointestinal tract and serve to promote or inhibit feeding, respectively (Antin et al., 1975; Tschöp et al., 2000; Nakazato et al., 2001). Emerging evidence suggests that some of these signals may also be produced centrally (Csajbók and Tamás, 2016). However, there are times when signals of energy homeostasis can be overridden. For example, when opting for dessert following an energy-repleting meal or when food-associated stimuli provoke feeding, even when sated (Weingarten, 1983). Oppositely, in anorexia, individuals can forgo eating even despite severe energy deficit (Berthoud, 2004; Kaye et al., 2013). These examples of so-called "nonhomeostatic" feeding, where a mismatch occurs between the motivation to eat and energy demand, has several evolutionary advantages but has re- 


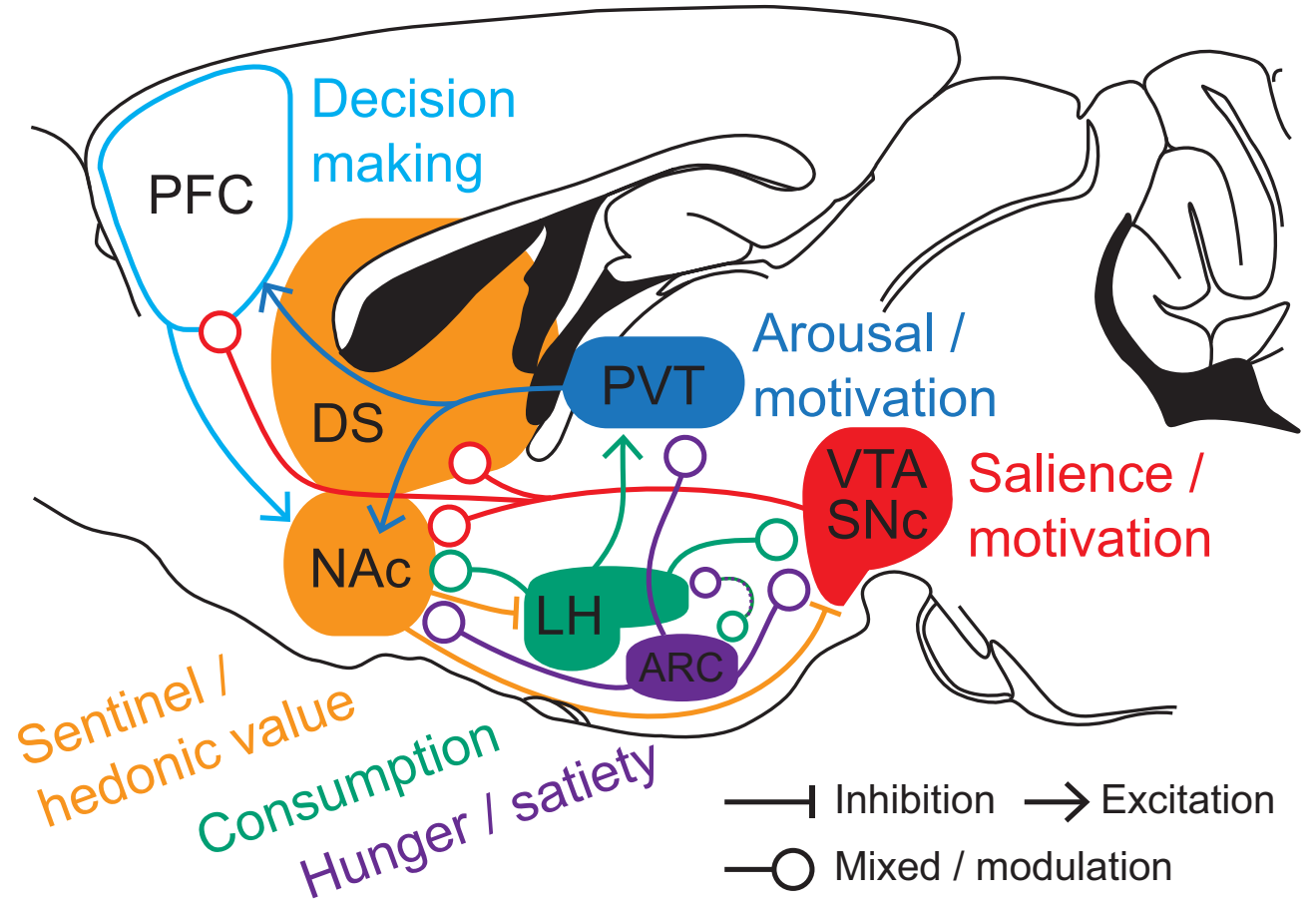

Figure 1. Major neural nodes controlling food intake. Major neural nodes involved in food intake control are shown in the rodent brain, together with their classically ascribed functions (Anand and Brobeck, 1951; Kelley et al., 2005; Palmiter, 2007; Berridge et al., 2010; Petrovich, 2013). For simplicity, the illustration does not show all interconnections and excludes some additional regions, including components of the MCL (e.g., hippocampus, basolateral amygdala, ventral pallidum) and output pathways. ARC, Arcuate nucleus; PFC, prefrontal cortex; SNc, substantia nigra pars compacta. Image adapted with permission from Franklin and Paxinos (2008).

cently gained recognition as being a defining feature of eating disorders and obesity (Zheng et al., 2009; Berridge et al., 2010; Petrovich, 2013; Brown et al., 2015a). Purely hedonic feeding is one component of nonhomeostatic feeding that has been reviewed (Berridge, 2009) and will not be a focus of this review.

Where in the brain does the battle between motivation and peripheral signals of energy homeostasis take place? Dopamine (DA) projections from the ventral tegmental area (VTA) to the medial prefrontal cortex, amygdala, hippocampus, and nucleus accumbens (NAc), and connections among these neural nodes form the mesocorticolimbic system (MCL; Fig. 1). This system is critically involved in generating motivated behaviors, including feeding (Kelley et al., 2005; Wise, 2006; Castro et al., 2015). In addition, hypothalamic and thalamic nuclei implicated in arousal, consumption and hunger; the paraventricular thalamic (PVT) nucleus, lateral hypothalamus (LH), and the ventromedial hypothalamus, respectively, interact closely with neural nodes of the MCL (Fig. 1). In the following review we take a neural circuits perspective and discuss how specific cell types in the MCL, hypothalamic, and thalamic nuclei interact and can be affected by signals of energy homeostasis to control motivated feeding behavior. We highlight how loss of control over MCL circuit activity by circulating signals of energy homeostasis could favor nonhomeostatic food intake, and how exposure to energy dense and palatable foods can induce persistent alterations in MCL activity, which may hold relevance for understanding the neural basis of eating disorders and obesity.

\section{VTA}

Located near the base of the midbrain, the VTA is the origin of DA neurons of the MCL, which comprise $~ 70 \%$ of all VTA neurons, in addition to GABA $(\sim 30 \%)$ and glutamate $(\sim 2 \%-3 \%)$ neurons (Nair-Roberts et al., 2008; Ungless and Grace, 2012)
(Fig. 2). VTA DA neurons respond to cues that predict rewards (Schultz et al., 1997) and are implicated as a key substrate in the incentive, reinforcing, and motivational aspects of food intake (Salamone et al., 2003; Wise, 2006; Fields et al., 2007; Palmiter, 2007; Narayanan et al., 2010).

Direct control of VTA by signals of energy homeostasis

Given the importance of VTA DA neurons in feeding (Salamone et al., 2003; Wise, 2006; Fields et al., 2007; Palmiter, 2007; Narayanan et al., 2010), it is of particular interest that they are subject to direct modulation from circulating signals of energy homeostasis (Palmiter, 2008; van Zessen et al., 2012). For example, leptin inhibits DA neuron activity and decreases food intake and effortful food seeking (Hommel et al., 2006; Domingos et al., 2011), whereas ghrelin increases VTA DA neuron activity and promotes food intake, effortful food seeking and favors consumption of palatable food over regular chow (Naleid et al., 2005; Abizaid et al., 2006; Zigman et al., 2006; Egecioglu et al., 2010; King et al., 2011; Skibicka et al., 2011). The appetite suppressant glucagonlike peptide-1 (GLP-1) also acts in the VTA to reduce high-fat diet intake, likely by reducing excitatory drive onto VTA DA neurons projecting to the NAc (Wang et al., 2015b).

Another important regulator of VTA activity is insulin, whose receptors are enriched on DA neurons (Figlewicz et al., 2003). When infused directly into the VTA, insulin reduces food anticipatory activity and decreases preference for a context previously associated with palatable food while not affecting effort to obtain food (Labouèbe et al., 2013). The synaptic mechanism of this effect involves an endocannabinoid-mediated, LTD of excitatory transmission onto VTA DA neurons (Labouèbe et al., 2013). Elevating endogenous insulin with a sweetened, high-fat meal subsequently occludes insulin-induced LTD onto VTA DA neurons, providing evidence of this mechanism occurring in a physiolog- 

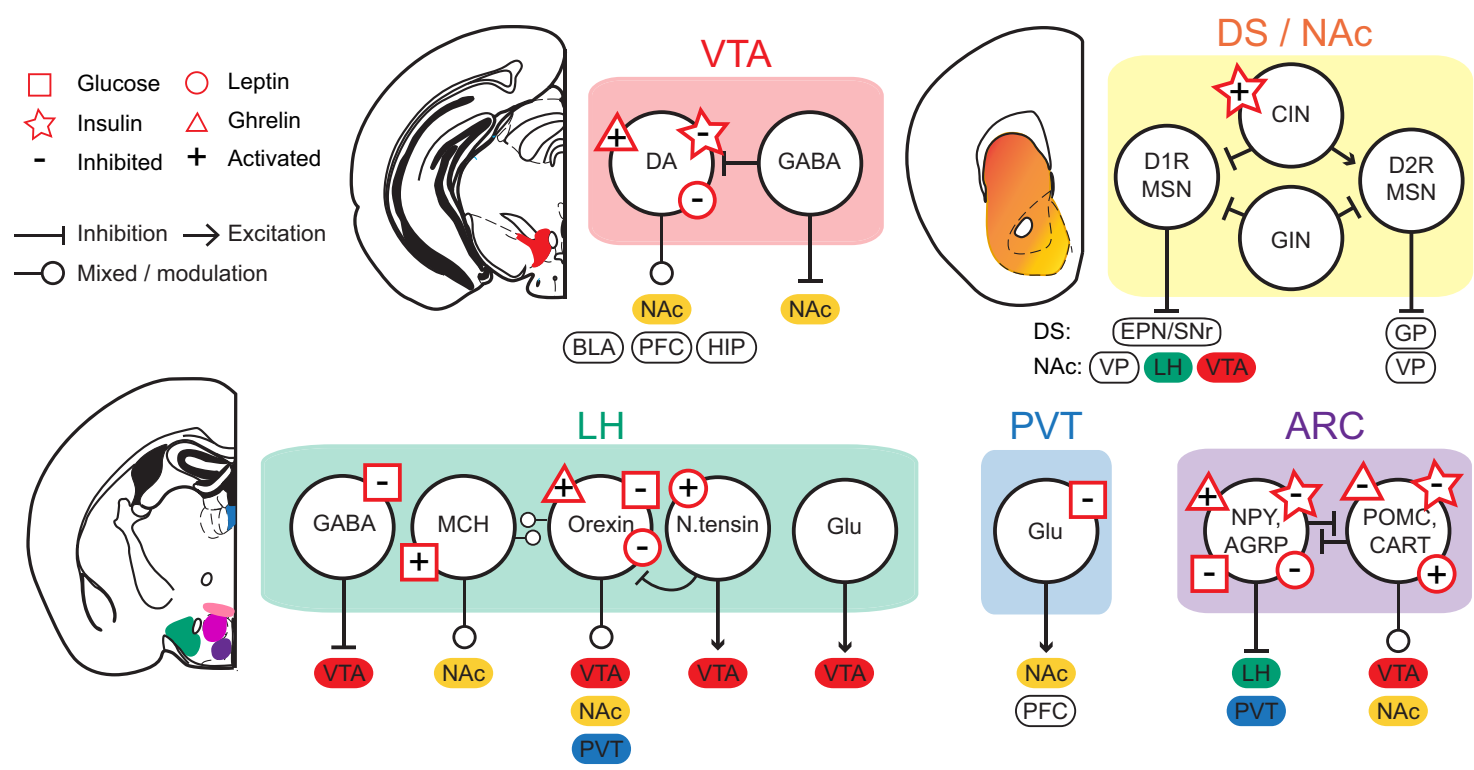

Figure 2. Multiple interactions between circuits of homeostasis and motivation. Microcircuitry of major neural nodes involved in food intake control (shown in Fig. 1) are shown in the rodent brain, together with known modulation of specific cell types by signals of energy homeostasis. To emphasize direct and indirect modulation of the MCL by circulating signals of energy homeostasis, only outputs from each region to other key nodes in the MCL are shown. For simplicity, not all known cell types, interconnections, and outputs are shown. ARC, Arcuate nucleus; BLA, basolateral amygdale; CART, cocaine- and amphetamine-regulated transcript; CIN, cholinergic interneuron; GIN, GABAergic interneuron; Glu, glutamate; HIP, hippocampus; MCH, melanin-concentrating hormone; NPY, neuropeptide Y; PFC, prefrontal cortex; VP, ventral pallidum. Images adapted with permission from Franklin and Paxinos (2008).

ically relevant situation (Labouèbe et al., 2013), although the precise relationship between central and peripheral insulin is still poorly understood. Collectively, these data suggest that insulin serves to regulate energy homeostasis in part by limiting the motivational drive of food-associated contextual cues by reducing excitatory drive onto VTA DA neurons.

VTA signaling is also implicated in the phenomenon of food priming; wherein brief exposure to palatable food drives future food approach and consumption that persists for days after the initial exposure (Liu et al., 2016). This effect is mediated by a rapid increase in synaptic density and excitatory synaptic transmission onto VTA DA neurons, which persists for at least $7 \mathrm{~d}$ (Liu et al., 2016). Suppressing excitatory transmission onto VTA DA neurons with insulin can reverse the behavioral effects of palatable food priming, whereas inhibition of insulin signaling immediately after palatable food consumption enables subsequent food approach behavior (Liu et al., 2016). These results suggest that even short-term exposure to palatable foods can prime future feeding behavior by "rewiring" VTA DA neurons. Interestingly, intranasal insulin has been shown to act on the CNS to suppress food consumption and attention to food-related cues (Kullmann et al., 2013). Thus, future studies should explore whether intranasal insulin could also be efficient to decrease food priming or food-associated cue-induced overeating.

Finally, the pathological relevance of insulin's effect on VTA DA neuron signaling has been investigated using a hyperinsulinemic mouse strain that is predisposed to obesity (Liu et al., 2013). In this mouse, insulin-induced LTD onto VTA DA neurons is disrupted, likely due to reduced VTA insulin receptor efficacy, because other forms of excitatory LTD in the VTA are unaffected (Liu et al., 2013). In the condition of hyperinsulinemia, it follows that insulin may be unable to suppress information transmitted to the VTA regarding food-associated cues, which could promote further food-seeking, even in an energy-replete state, leading to weight gain and obesity.

\section{LH-VTA projections linking homeostasis to motivation}

As well as direct modulation of VTA DA neurons, inputs to VTA from brain areas that monitor metabolic need provide additional, indirect routes to translate these needs into behavioral output. In this regard, a notable example is LH (Fig. 2), which runs the length of the hypothalamus lateral to the fornix (Hahn and Swanson, 2010) and provides major direct innervation of VTA, as identified by electrophysiology (Bielajew and Shizgal, 1986; Gratton and Wise, 1988), viral tracing (Watabe-Uchida et al., 2012), and optogenetic phototagging (Nieh et al., 2015). Initial studies of LH found that lesions led to fatal anorexia, whereas electrical stimulation triggered intense feeding, leading to the description of LH as a "feeding center" (Anand and Brobeck, 1951; Delgado and Anand, 1953). However, this initial description was an oversimplification (King, 2006), as decades of additional studies have shown that LH contributes not only to feeding behavior, but also to energy balance, arousal, reward, and motivated behaviors (for review, see Bonnavion et al., 2016). Recent studies suggest that the projection from LH to VTA (LH-VTA) plays a major role in these functions.

The LH-VTA projection is heterogeneous and composed of neurons releasing glutamate or GABA (Nieh et al., 2015, 2016), as well as neuropeptides, including orexin/hypocretin (Harris et al., 2005; Borgland et al., 2006, 2008) and neurotensin (Leinninger et al., 2011; Kempadoo et al., 2013; Opland et al., 2013) (Fig. 2). Optogenetic stimulation of the bulk LH-VTA projection was shown to support intracranial self-stimulation (Kempadoo et al., 2013) and reinforce compulsive sucrose-seeking (Nieh et al., 2015). Indeed, Nieh et al. (2015) found that mice were more willing to endure foot-shocks to obtain a sugar reward when the LH-VTA projection was stimulated. In this study, in vivo multiunit recordings revealed that the LH-VTA projection specifically encodes the conditioned response (i.e., the action of obtaining the sucrose reward only after the CS-US pairing was learned) (Nieh et al., 2015). 
With bulk optogenetic stimulation of LH-VTA projections, Kempadoo et al. (2013) demonstrated that the ability of this pathway to support ICSS required activation of neurotensinreceptor-1 and NMDARs in the VTA. However, Nieh et al. (2016) later found that optogenetic stimulation of the isolated LH-VTA glutamate projection did not support ICSS and instead led to aversion when assayed in a real-time place preference task. Instead, it has been proposed that the LH-VTA GABA projection provides the rewarding and feeding effects seen in stimulation of bulk LH-VTA projections (Nieh et al., 2015, 2016; Barbano et al., 2016), acting to disinhibit VTA DA neurons and increase DA release in the NAc via inhibition of local VTA GABA neurons (Nieh et al., 2016). Moreover, optogenetic inhibition of the LHVTA GABA projection was found to decrease feeding in hungry animals, demonstrating the necessity, in addition to the sufficiency, of this projection for driving feeding behaviors (Nieh et al., 2016).

Depending on the environment or context, the LH-VTA GABA projection actually has the capacity to support a variety of motivated behaviors. In the presence of food, stimulation of this projection evokes feeding (Nieh et al., 2015), but in the presence of a social cue or novel object, stimulation evokes interaction or investigation, respectively (Nieh et al., 2016). This suggests that stimulation of the LH-VTA GABA projection may serve to increase an animal's motivation to fulfill a need, and the action that is taken will differ depending on the state of the animal. Thus, with respect to feeding, the LH-VTA GABA projection likely modulates the behavioral activation required to cause an animal to eat while the processing of cues that necessitate feeding are processed upstream and the motor actions of feeding are processed downstream (Nieh et al., 2016).

In addition to LH GABA or glutamate inputs, VTA DA neurons are also subject to modulation from LH-derived neuropeptides. Of note are hypocretin/orexin (Hcrt/Ox) neurons, which are found only in the lateral, perifornical, and dorsomedial hypothalamus (Harris and Aston-Jones, 2006). LH Hcrt/Ox signaling is associated with increased food intake (Sakurai et al., 1998), driven by excessive food seeking (Barson et al., 2013). Hcrt/Ox neurons are sensitive to metabolic status and are activated during energy deficit (Cai et al., 1999, 2001). Specifically, ghrelin directly activates Hcrt/Ox neurons (Sheng et al., 2014), whereas leptin indirectly inhibits them. This inhibition arises from presynaptic leptin receptor-expressing neurotensin and/or GABA neurons (Leinninger et al., 2011; Sheng et al., 2014). The net effect of Hcrt/Ox signaling in VTA is to promote DA neuron activity by enhancing excitation and suppressing inhibition onto these neurons (Borgland et al., 2006; Baimel et al., 2015). Blockade of VTA orexin-1 receptors drives rats to switch choice from high-effort, high-fat pellets to low-effort, regular food (Thompson and Borgland, 2011). Thus, by promoting DA release, the LH-VTA Hcrt/Ox projection allows the transfer of metabolic information to drive motivated behavior necessary to obtain salient rewards (Harris and Aston-Jones, 2006; Harris et al., 2007; Cason and Aston-Jones, 2013).

The Hcrt/Ox neurons also belong to the glucose-inhibited subtype of glucose-sensing neurons (Burdakov et al., 2005). Sheng et al. (2014) have found that both fasting and ghrelin enhance activation of Hcrt/Ox neurons in low glucose, whereas leptin does the converse. One possibility is that the glucosesensing function of Hcrt/Ox neurons could be important for linking metabolic need to the motivated behavior required to obtain food via alterations of VTA DA neuron signaling. Using a horizontal acute brain slice that contains both LH and VTA,
Sheng et al. (2014) found that lowering glucose concentration increased glutamatergic EPSCs onto VTA DA neurons. Moreover, this effect was blocked by an orexin-1 receptor antagonist. These data lend support to the hypothesis that activation of Hcrt/Ox neurons by low glucose may enhance food-motivated behavior, especially in the fasted state, via downstream actions on VTA DA neurons. Such reinforcement of reward-based feeding behavior by LH Hcrt/Ox glucose-inhibited neurons could contribute to the difficulty in maintaining weight loss after dieting.

Much progress has been made in dissecting LH-VTA circuitry, yet important challenges remain. One is that subpopulations of $\mathrm{LH}$ neuropeptide releasing cells also have the capacity for GABA and/or glutamate synthesis and/or release (Meister, 2007; Schöne and Burdakov, 2012; Jego et al., 2013; Chee et al., 2015). It will be critical to understand whether corelease of LH peptides with different neurotransmitters from the same axon represents a physiologically important function at LH-VTA synapses. Second, LH can also control VTA indirectly via glutamatergic projections to the lateral habenula, whose stimulation suppresses food intake (Stamatakis et al., 2016). It is not known how information is routed between these indirect versus direct LH-VTA projections. Third, LH GABA neurons show heterogeneity in their neuronal responses during food seeking and consumption (Jennings et al., 2015). It is not known whether such heterogeneity is segregated among the different projections of these neurons, including those innervating VTA. Finally, LH also contains a distinct, non-Hcrt/Ox-expressing population of GABA neurons (Karnani et al., 2013; Jennings et al., 2015; O'Connor et al., 2015), some of which are glucose inhibited (Karnani et al., 2013). Other LH neuropeptide populations have also been described, including neuropeptide $\mathrm{Y}$, thyrotropin-releasing hormone, encephalin, and urocortin-3 expressing neuron populations (Marston et al., 2011; Bonnavion et al., 2016) and glucose activated melanin-concentrating hormone neurons (Qu et al., 1996; de Lecea et al., 1998; Burdakov et al., 2005). Clearly, then, LH neurons are as diverse as their functions, and it will be important to dissect how this complex microcircuit operates to determine LH output in both healthy and disease states.

\section{Striatum}

A major target of midbrain DA neurons is the striatum, which is broadly divided into dorsal striatum (DS) and ventral (NAc core and shell) regions. Across the striatum, the majority (90-95\%) of neurons are inhibitory medium-sized spiny neurons (MSNs), divisible into approximately two equal populations based on their projections and/or expression of DA D1R or D2R receptors (Fig. 2) (Beckstead and Cruz, 1986; Gerfen et al., 1990; Meredith et al., 2008; Bertran-Gonzalez et al., 2010; Kupchik et al., 2015). Local interneurons comprise the remaining fraction of cells and include large cholinergic interneurons and GABA interneurons, which play key roles in coordinating striatal activity (Tepper and Bolam, 2004; Gittis and Kreitzer, 2012).

Dorsal and ventral striatum have distinct inputs, outputs, and roles in behavior (Sesack and Grace, 2010; Kupchik et al., 2015; Yager et al., 2015). In brief, DS integrates DA signals arising from the substantia nigra pars compacta with glutamate input from sensorimotor cortical areas and thalamus, and sends inhibitory projections via D1R-MSNs to output nuclei of the basal ganglia (EPN and SNr), or via D2R-MSNs to the globus pallidus, forming the "direct" and "indirect" pathways, respectively (Gerfen et al., 1990). These pathways play a critical role in the bidirectional regulation of motor behavior (Kravitz et al., 2010; Cui et al., 2013), but also in reinforcement learning and punishment (Balleine, 2005; Kravitz et al., 2012). 
The accumbens integrates VTA DA signals with glutamate inputs from the hippocampus, amygdala, prefrontal cortex, and PVT nucleus. The NAc is also a target of many direct and indirect inputs from hypothalamic regions (Opland et al., 2010). A number of peptides and hormones, including GLP-1, leptin, insulin, endogenous opioids, and ghrelin, can also alter NAc activity and function (Perry et al., 2010; Castro and Berridge, 2014; Stouffer et al., 2015; Dailey et al., 2016; Hayes and Schmidt, 2016). Unlike DS, the projection pattern of NAc MSNs is not clearly segregated according to DA receptor expression. Both D1R- and D2R-MSNs innervate the ventral pallidum (Kupchik et al., 2015), whereas D1R-MSNs form the major projection from accumbens to LH (O'Connor et al., 2015) and VTA (Bocklisch et al., 2013). The function of accumbens is perhaps best described as a "limbicmotor interface" (Mogenson et al., 1980), playing a critical role in conditioned motivation, hedonic evaluation, and acting as a "sensory sentinel" to allow flexible control of consumption via its descending projections to premotor effector areas (Taha and Fields, 2005; Baldo and Kelley, 2007; Berridge et al., 2010; O'Connor et al., 2015).

Given the powerful regulation of midbrain DA neurons by circulating signals of energy homeostasis (see VTA), it is valuable to briefly consider the role of DS and NAc DA signaling in feeding behavior, and how perturbation of striatal function may have relevance for feeding disorders and obesity (Tomasi and Volkow, 2013; see also Kenny et al., 2013).

\section{Dorsal striatum DA and feeding behavior}

Initial evidence supporting a critical role of DS DA signaling in feeding came from DA-depleted mice, which do not eat and will starve without intervention (Szczypka et al., 2001). Restoration of DA selectively in the DS, but not NAc, is sufficient to enable these animals to eat and survive (Szczypka et al., 2001; Sotak et al., 2005; Hnasko et al., 2006). Impaired feeding in DA-depleted mice does not reflect a deficit in the ability to eat per se, or in the perception of signals of energy homeostasis, but rather a failure to initiate feeding behavior (Cannon and Palmiter, 2003; Palmiter, 2008). Thus, DS DA signaling may serve as a permissive, "action initiation" signal, enabling animals to orient their attention toward nutritive food retrieval and consumption in response to metabolic demand (Palmiter, 2008).

NAc DA and feeding behavior

NAc DA regulates feeding in a manner distinct to that of DS. In the NAc, food rewards and food-predictive cues increase local DA levels (Brown et al., 2011; Cone et al., 2015). Notably, foodevoked DA release is amplified in food-deprived animals (Avena et al., 2008) and food cue-evoked DA release is augmented in animals injected with the hunger signal ghrelin (Cone et al., 2015). Ablation of NAc-projecting DA neurons or intra-NAc DA receptor antagonist microinjection disrupts effort-related and anticipatory aspects of feeding but has only subtle effects on the microstructure of food consumption (Nowend et al., 2001; Salamone et al., 2001; Baldo et al., 2002; Baldo and Kelley, 2007). Conversely, elevating NAc DA with intra-accumbens amphetamine microinjection increases effortful food seeking (Zhang et al., 2003). Together, NAc DA signaling appears critical for augmenting the salience of food-related stimuli, with a consequent increase in effort directed at obtaining food (Hanlon et al., 2004; Aitken et al., 2016). The regulation of NAc-projecting DA neurons by circulating signals of energy homeostasis would therefore allow the salience of food-related stimuli and subsequent effortful food seeking to be closely coupled with internal energy demands.
Striatal cell types controlling feeding behavior

The global functions of DS and NAc in feeding behavior have been well characterized, but how these functions are encoded by specific striatal cell types and how such cells may be affected by circulating signals of energy homeostasis is only just beginning to be understood. One recent intriguing finding is that activation of insulin receptors on striatal cholinergic interneurons increases local DA release in both DS and NAc and enhances sucrose preference behavior (Stouffer et al., 2015). Notably, this effect is amplified in food-restricted animals and blunted in rats fed an obesigenic diet (Stouffer et al., 2015). In addition, insulin enhances both excitatory transmission onto NAc neurons and cue-triggered food seeking (C.R.F., unpublished observations). However, it is not known how the effects of insulin in the NAc interact with insulin-induced LTD in the VTA, and questions remain regarding how local effects of insulin are related to peripheral insulin signals. Nevertheless, together, these data support the idea that insulin normally serves to enhance striatal activity and motivation.

Regarding the principal striatal cell type, the MSN, lickcontingent optogenetic stimulation of DS D1R-MSNs was found to increase intake of a noncaloric sweetener (sucralose) and annulled aversion to an adulterated bitter solution (Tellez et al., 2016). The same manipulation in NAc D1R- or D2R-MSNs also enhanced sweetener intake but did not attenuate aversion to the bitter solution (Tellez et al., 2016). These data, together with findings from in vivo DA measurements and cell-ablation studies, suggest that DA levels in DS and NAc, acting via D1R-MSNs, signal the nutritive and gustatory quality of sugar, respectively, and that DS output may serve to prioritize energy seeking over taste quality (Tellez et al., 2016; de Araujo, 2016). Surprisingly, in vivo recordings of NAc D1R-MSNs found that the activity of these neurons reduced during palatable food consumption and, consistent with this observation, noncontingent optogenetic inhibition of NAc D1R-MSNs prolonged food intake (O'Connor et al., 2015). Moreover, lick-contingent and noncontingent optogenetic stimulation of D1R-MSN projections to LH inhibited palatable food intake, even in food deprived mice, suggesting that the NAc D1R-MSN to LH pathway may serve to override immediate metabolic need and allow rapid consumption control in response to changing external stimuli (O'Connor et al., 2015). The contradictory findings between these two studies may reflect further segregation of NAc D1R-MSN function according to projection targeting of the ventral pallidum (Tellez et al., 2016) or LH (O'Connor et al., 2015). Indeed, stimulation of dynophinergic cells (i.e., predominantly D1R-MSNs) in the dorsal or ventral NAc shell induces reinforcement or aversion, respectively (AlHasani et al., 2015), although the projection targets of these functionally opposing populations are not known. No doubt, further understanding of striatal subcircuitry, both at the level of distinct inputs to striatum and its output pathways, will greatly improve our overall understanding of the integration of the regulation of feeding by homeostatic and motivational systems.

\section{Altered striatal function and obesity}

Human neuroimaging studies have provided important insight into the control of food intake by striatal DA and its dysregulation in obesity (for review, see Small, 2009; Stice et al., 2013). A central observation is that, compared with normal weight controls, overweight and obese humans show reduced striatal D2R availability (Wang et al., 2001; Stice et al., 2008b; Kenny et al., 2013) and individuals with the Taq1A A1 allele, which is associated with reduced D2R expression, are more likely to be obese (Stice et al., 
2008b). Obese and overweight individuals also show enhanced striatal activation in response to food-predictive cues (Rothemund et al., 2007; Stoeckel et al., 2008; Demos et al., 2012), but reduced striatal activation following palatable food receipt (Stice et al., 2008a, b; Babbs et al., 2013). Importantly these striatal reactivity observations, which may reflect reward prediction error signals (Kroemer and Small, 2016), are also predictive of future weight gain, indicating that striatal network activity is closely linked with the development of obesity (Stice et al., 2010, 2015; Demos et al., 2012).

The role of striatal DA signaling in obesity has been further explored in rodent studies. In the dorsal striatum, prolonged access to an energy dense "cafeteria style" diet has been found to decrease (Johnson and Kenny, 2010) or increase D2R expression (Valenza et al., 2015), whereas genetically obese Zuker rats show reduced DS D2R levels (Thanos et al., 2008). Interestingly, rats with extended access to cafeteria style diet become resistant to punishment associated with feeding and show deficits in brain reward function, as measured by elevated brain-stimulation reward thresholds (Johnson and Kenny, 2010). In addition, viralmediated knockdown of DS D2Rs mimics effects of cafeteria diet on self-stimulation and resistance to punishment, but not obesity, suggesting a functional coupling at the level of DS D2Rs between reduced brain reward function and compulsive food consumption (Johnson and Kenny, 2010).

In the NAc, research on the effects of obesity has revealed that both the type of nutrients consumed and physiological changes accompanying obesity can alter the function of this structure. For example, chronic overconsumption of saturated but not monounsaturated dietary lipids dampens NAc DA signaling in the absence of obesity (Hryhorczuk et al., 2016) and consumption of triglycerides acutely reduces food-seeking behavior (Cansell et al., 2014). Diet and obesity also induce changes in NAc DA receptor expression and transmission, which differ between obesitysusceptible and resistant populations (Geiger et al., 2009; Robinson et al., 2015; Valenza et al., 2015; Vollbrecht et al., 2016). These data lend support to the idea that individual susceptibility to obesity influences both neural and behavioral observations that promote weight gain (Stice et al., 2008b; Felsted et al., 2010; Albuquerque et al., 2015). In addition to changes in NAc DA signaling, diet-induced obesity impairs subsequent glutamatergic plasticity in the NAc, particularly in obesity-susceptible rats (Brown et al., 2015b). Consumption of sugar also enhances excitatory transmission mediated by AMPA receptors onto NAc neurons (Tukey et al., 2013; Counotte et al., 2014), whereas consumption of a "junk-food" diet enhances transmission mediated by calcium-permeable AMPARs in the NAc (Oginsky et al., 2016). In these studies, diet-induced alterations in NAc function occurred in the absence of obesity, suggesting that these changes may drive overconsumption that promotes subsequent weight gain. Diet-induced increases in NAc calcium-permeable AMPARs are particularly interesting because these receptors mediate enhanced cue-triggered drug craving (Loweth et al., 2014; Lüscher, 2016; Terrier et al., 2016; Wolf, 2016) and cue-induced motivation for food is enhanced in obese and obesity-susceptible rats and humans (Small, 2009; Stice et al., 2013; Brown et al., 2015b; Robinson et al., 2015).

Together, findings from human and rodent studies have led some to propose a model in which overeating may occur to compensate for preexisting striatal hypoactivity and reward deficiency, which may further attenuate the responsiveness of this circuit in a feedforward process (Stice et al., 2010; O'Connor and Kenny, 2016). However, reduced striatal D2R expression is seen in rodents fed a junk-food diet regardless of the whether they develop obesity or not (Robinson et al., 2015), suggesting that this striatal adaptation cannot fully explain maladaptive weight gain (Kroemer and Small, 2016). A more parsimonious explanation emerging from the literature is one in which individual susceptibility interacts with the types of foods consumed to alter striatal function and promote cue-induced food-seeking behavior (Stice et al., 2008b, 2009; Stoeckel et al., 2008; Felsted et al., 2010; Albuquerque et al., 2015; Brown et al., 2015b; Robinson et al., 2015). This chain of events may then be further exacerbated by increased adiposity and metabolic dysfunction that characterize obesity. In future work, it will be critical to resolve and dissociate signaling pathways linking obesity and consumption of energy dense and palatable foods with altered food seeking behavior and striatal function (including other molecular changes not discussed here) (Alsiö et al., 2010; Baladi et al., 2012; Robinson et al., 2015; Valenza et al., 2015; Hryhorczuk et al., 2016) and to understand how such alterations may vary in obesitysusceptible versus resistant individuals.

\section{PVT-NAc projections controlling motivated feeding}

A major glutamate input to accumbens arises from the PVT, which has recently emerged as an important structure in the regulation of motivated feeding (Fig. 2). Like other thalamic nuclei, PVT exhibits a high density of glutamatergic neurons (Watson, 2012), with neuronal subpopulations classified according to calcium binding protein expression or diverse neuropeptides (Kirouac, 2015), but almost no GABA cells (Watson, 2012). PVT receives strong inputs from feeding-related hypothalamic areas, including LH orexin neurons, ARC neurons expressing agoutirelated peptide (AGRP), and cocaine- and amphetamineregulated transcript (Parsons et al., 2006; Lee et al., 2015) and from cortical areas linked to decision making (Kirouac, 2015). Via a dense bundle of primarily glutamatergic fibers, PVT innervates NAc shell and other MCL nodes, including medial prefrontal cortex, amygdale, and bed nucleus of the stria terminalis (Parsons et al., 2006; Vertes and Hoover, 2008). These anatomical observations have led to the proposal that PVT serves as an integrative relay, conveying feeding-related information from hypothalamic areas to the MCL (Kelley et al., 2005; Parsons et al., 2006; Martin-Fardon and Boutrel, 2012) and thereby influencing motivation to seek rewards (Matzeu et al., 2014; Kirouac, 2015). Recent studies have begun to add functional support to these ideas. For example, Haight et al. (2015) have shown that PVT influences the motivation of rats to respond to food-predictive cues, whereas optogenetic activation of AGRP projections to the PVT or intra-PVT infusion of the GABAa receptor antagonist muscimol is sufficient to elicit feeding in rodents (Betley et al., 2013; Stratford and Wirtshafter, 2013).

Little is known about how signals of energy homeostasis directly influence PVT output, although receptors for leptin and GLP-1 are present in PVT (De Matteis and Cinti, 1998; Cork et al., 2015) and indirect modulation via $\mathrm{LH}$ and ARC inputs is likely. However, PVT contains neurons that respond to neuroglucopenia, a condition that mimics hypoglycemia, as shown by strong neuronal activation observed in PVT following 2-deoxyglucose injection in rats (Dodd et al., 2010). In line with this observation, Labouèbe et al. (2016) recently identified a population of PVT glutamate neurons which project to NAc MSNs and express Glut2, a glucose transporter implicated in the detection of glucose in both pancreatic $\beta$ cells and the CNS (Lamy et al., 2014; Tarussio et al., 2014). These PVT Glut2-positive neurons increase their firing frequency when extracellular glucose 
concentration drops below normoglycemic levels, and mice lacking Glut2 in PVT neurons make more effort to obtain sucrose, but not the noncaloric reward saccharin (Labouèbe et al., 2016). Optogenetic activation of PVT Glut2-expressing projections to the NAc shell was used to mimic hypoglycemia and thus test causality between increased activity of PVT Glut 2 neurons and the motivation to seek sucrose. Indeed, this manipulation was sufficient to enhance effortful sucrose seeking in mice (Labouèbe et al., 2016). Together, these data link regulation of PVT activity by circulating glucose levels to the control of motivated, effortful food seeking.

The regulation of motivated sucrose seeking by PVT Glut2 neurons projecting to NAc may occur via the modulation of presynaptic accumbal DA levels (Parsons et al., 2007). However, a functional link between accumbal DA and PVT-dependent motivated feeding behavior remains to be clearly demonstrated. Nevertheless, findings reviewed here draw interesting parallels with a similar phenotype observed in humans, wherein a Glut2 gene variant (Thr110Ile) is associated with higher sugar intake (Eny et al., 2008). In addition, PVT activation was reported as exacerbated in obese rats following food deprivation (Timofeeva and Richard, 2001). Thus, further investigations into the cellular, synaptic, and circuit mechanisms controlling PVT activity may provide valuable new insight into eating disorders and obesity.

\section{Arcuate (ARC) nucleus of the hypothalamus}

Early studies of lesions to the basomedial part of the hypothalamus, which includes the ARC and ventromedial hypothalamus nuclei, resulted in profound hyperphagia and obesity, and thus provided the first evidence linking the function of these nuclei to the maintenance of energy homeostasis (Hetherington and Ranson, 1940). Mechanisms underlying the hunger and satiety inducing functions of basomedial hypothalamic nuclei have been subject of intense research efforts and are reviewed previously (Meister, 2007; Pandit et al., 2013; Sternson, 2013; Webber et al., 2015; Sutton et al., 2016). Here we focus on recent findings that have elucidated the motivational characteristics of neurons embedded within ARC (Fig. 2).

\section{AGRP and pro-opiomelanocortin (POMC) neurons in} motivated feeding

ARC is home to $\sim 10,000$ neurons that coexpress AGRP with neuropeptide-Y and release GABA (Betley et al., 2013). These AGRP neurons are activated by ghrelin (Cowley et al., 2003; van den Top et al., 2004; Yang et al., 2011) and inhibited by leptin (van den Top et al., 2004), insulin (Schwartz et al., 1992; Könner et al., 2007), and glucose (Fioramonti et al., 2007). Optogenetic (Aponte et al., 2011) or chemogenetic (Krashes et al., 2011) activation of AGRP neurons rapidly elicits voracious feeding behavior within minutes, and transient inhibition of these neurons reduces appetite (Krashes et al., 2011; Betley et al., 2015). Moreover, AGRP neuron activation also increases the willingness to work for food (Krashes et al., 2011; Atasoy et al., 2012; Betley et al., 2015). AGRP neurons receive excitatory drive from paraventricular hypothalamus (PVH) (Krashes et al., 2014), and monosynaptically inhibit local POMC neurons (Cowley et al., 2001; Atasoy et al., 2012), whereas stimulation of AGRP projections to the anterior BNST, PVH, PVT, and LH promotes food intake (Atasoy et al., 2012; Betley et al., 2013; Garfield et al., 2015).

The motivated processes associated with AGRP neurons have been investigated by cell type-specific activity perturbations (Betley et al., 2015). AGRP neuron activation was shown to transmit a negative valence signal that influences learning such that mice can be conditioned to avoid a flavor or a place that was associated with optogenetic AGRP neuron activation. Conversely, cues associated with a reduction of AGRP neuron activity during deprivation-induced hunger were preferred. This negative valence property of elevated AGRP neuron activity is consistent with human self-reporting about the unpleasantness of hunger. However, it is seemingly paradoxical that a neuron population that avidly elicits food intake would also lead to avoidance behaviors. It would be ethologically contradictory for an animal to avoid environmental cues that predict food.

To resolve these issues, the endogenous activity dynamics of AGRP neurons during feeding behaviors were monitored by bulk fluorescence of population calcium activity (Chen et al., 2015), single-cell-resolution calcium imaging (Betley et al., 2015), and phototagging electrophysiological recording (Mandelblat-Cerf et al., 2015). These methods showed that, in food-deprived mice, AGRP neurons reduced activity upon presentation of food within seconds, even before food was consumed. Specifically, in vivo deep-brain calcium imaging revealed that $96 \%$ of AGRP neurons rapidly reduced activity upon the sight of food or a foodpredictive auditory cue (Betley et al., 2015), whereas in vivo tetrode recordings found that $\sim 60 \%$ of AGRP neurons reduced activity at meal onset (Mandelblat-Cerf et al., 2015). These contrasting results likely reflect different sensitivities between the two recording techniques used. Nevertheless, activity of the majority of AGRP neurons is low during food consumption, suggesting that AGRP neurons are involved in food seeking, but not food consumption.

Rapid AGRP neuron inhibition by food presentation was shown to involve learning. Neutral cues that initially have little influence on AGRP neuron activity come to rapidly reduce AGRP neuron activity after they have been repeatedly associated with food delivery (Betley et al., 2015). However, food consumption is required to sustain reduced AGRP neuron activity, which is consistent with the homeostatic role of these neurons (Betley et al., 2015).

Together, homeostatic AGRP neurons motivate behavior by a negative valence signal of homeostatic need and also reinforce preference for environmental cues that lead to prolonged reduction of their activity. This may explain the paradox of why mice eat in response to negative valence AGRP neuron activation. Eating is a previously learned behavior that reduces negative valence AGRP neuron activity, reinforces approach to food-associated cues, and thus becomes reliably adopted as the animal's response to elevated activity of these neurons. Perhaps the closest similarity of this process for people is the intense and unpleasant motivational properties of starvation, which is even experienced in food-abundant societies. For instance, on a weight-loss diet, the negative emotional aspects of the AGRP neuron activity likely contribute to the high failure rate for dieting.

In addition to AGRP neurons, ARC also contains neurons coexpressing POMC and cocaine- and amphetamine-regulated transcript release the anorexigenic signal $\alpha$-melanoycte stimulating hormone ( $\alpha$-MSH). These POMC neurons are activated by leptin to decrease food intake (Elias et al., 1999; Cowley et al., 2001; Vong et al., 2011) and inhibited by insulin (Williams et al., 2010) and ghrelin (Chen et al., 2015). Both acute (Steculorum et al., 2016) and chronic (Zhan et al., 2013) chemogenetic activation of POMC neurons inhibits feeding and body weight gain, whereas chronic chemogenetic inhibition of these neurons increased food intake (Atasoy et al., 2012). In addition to a role in food consumption, real-time population recordings of calcium activity revealed that POMC neurons are also activated solely 
upon food presentation; an effect modulated by both food quality and metabolic state (Chen et al., 2015). This finding suggests an important role for these neurons in sensory detection and the control of appetitive behaviors, such as foraging. POMC neurons innervate adjacent hypothalamic nuclei, including LH (King and Hentges, 2011), PVH (Wang et al., 2015a) and key neural nodes of the MCL, including the VTA and NAc (King and Hentges, 2011; Lim et al., 2012). Notably, intra-VTA $\alpha$-MSH increases NAc DA levels (Lindblom et al., 2001), whereas $\alpha$-MSH signaling in the NAc is implicated in the anorectic effects of chronic stress (Lim et al., 2012). Thus, projections of POMC neurons to the MCL may serve as an important bridge linking energy sensing to neural circuits controlling motivated behavior.

\section{Conclusion}

In conclusion, our review has focused on feeding behavior, which represents just one element involved in the complex regulation of energy homeostasis and body weight. We have reviewed how distinct anatomical regions are involved in several components of feeding behavior, from generating a negative valence teaching signal to supporting effortful food seeking, choice, consumption, and postingestive learning. Indeed, classical models have emphasized the assignment of specific feeding-related functions to distinct regions of "reward" and "homeostasis" brain networks (Berridge, 1996; Berthoud, 2004; Palmiter, 2007). However, our review also illustrates the enormous amount of interconnectivity been these different regions and networks and highlights the need to better understand how information is communicated among them to ultimately determine food intake. This challenge is daunting but may now be realized with the advent of multisite in vivo imaging (Kim et al., 2016) and whole-brain activity mapping (Renier et al., 2016).

The MCL has long been recognized as a key substrate in motivated feeding and is subject to powerful modulation from circulating signals of energy homeostasis acting directly on local neurons, or indirectly via hypothalamic and thalamic inputs. We have highlighted studies in which consumption of fatty, sugary, "junk foods" and obesity can produce long-lasting alterations in the MCL system, and how the regulation of MLC activity is differentially altered by signals of homeostasis in the normal and obese state. Thus, when signals of homeostasis lose the battle to control neural circuits of motivation, inappropriate, nonhomeostatic feeding can dominate. However, it must be noted that many studies reviewed here have elucidated neural circuits involved in the immediate control of food intake, but in many cases it is not known whether perturbed function of these circuits could be sufficient to drive long-term changes in body weight relevant to feeding disorders and obesity. This represents an important and exciting avenue of research, particularly as the underlying cell types become increasingly well-defined and accessible for recording and manipulation. An important challenge will be to identify mechanisms that prevent or reverse maladaptive feeding behaviors, which in turn may inspire new treatment options for eating disorders and obesity.

For many, being overweight or obese results from increased intake of easily available, energy-dense, high-fat, high-sugar foods together with increased physical inactivity (World Health Organisation, 2016). Much can be done at the societal level to limit the so-called "obesity pandemic," including increasing access to affordable, healthy dietary choices and promoting physical activity (Cawley, 2016). However, modifications in diet and exercise can be difficult to maintain (Langeveld and DeVries, 2015) and, particularly for eating disorders such as anorexia, treatment options are limited and inconsistently applied (Hart et al., 2013). In this regard, neuroscience research stands ideally poised to influence global policy and treatment provision for obesity and eating disorders in offering a better understanding of how neural circuits operate to determine food-related choices.

\section{References}

Abizaid A, Liu ZW, Andrews ZB, Shanabrough M, Borok E, Elsworth JD, Roth RH, Sleeman MW, Picciotto MR, Tschöp MH, Gao XB, Horvath TL (2006) Ghrelin modulates the activity and synaptic input organization of midbrain dopamine neurons while promoting appetite. J Clin Invest 116: 3229-3239. CrossRef Medline

Aitken TJ, Greenfield VY, Wassum KM (2016) Nucleus accumbens core dopamine signaling tracks the need-based motivational value of food-paired cues. J Neurochem 136:1026-1036.

Albuquerque D, Stice E, Rodríguez-López R, Manco L, Nóbrega C (2015) Current review of genetics of human obesity: from molecular mechanisms to an evolutionary perspective. Mol Genet Genomics 290:11911221. CrossRef Medline

Al-Hasani R, McCall JG, Shin G, Gomez AM, Schmitz GP, Bernardi JM, Pyo CO, Park SI, Marcinkiewcz CM, Crowley NA, Krashes MJ, Lowell BB, Kash TL, Rogers JA, Bruchas MR (2015) Distinct subpopulations of nucleus accumbens dynorphin neurons drive aversion and reward. Neuron 87:1063-1077. CrossRef Medline

Alsiö J, Olszewski PK, Norbäck AH, Gunnarsson ZE, Levine AS, Pickering C, Schiöth HB (2010) Dopamine D1 receptor gene expression decreases in the nucleus accumbens upon long-term exposure to palatable food and differs depending on diet-induced obesity phenotype in rats. Neuroscience 171:779-787. CrossRef Medline

American Psychiatric Association (2015) Feeding and eating disorders. Arlington, VA: American Psychiatric Association.

Anand BK, Brobeck JR (1951) Localization of a "feeding center" in the hypothalamus of the rat. Proc Soc Exp Biol Med 77:323-324. CrossRef Medline

Antin J, Gibbs J, Holt J, Young RC, Smith GP (1975) Cholecystokinin elicits the complete behavioral sequence of satiety in rats. J Comp Physiol Psychol 89:784-790. CrossRef Medline

Aponte Y, Atasoy D, Sternson SM (2011) AGRP neurons are sufficient to orchestrate feeding behavior rapidly and without training. Nat Neurosci 14:351-355. CrossRef Medline

Arnold M, Leitzmann M, Freisling H, Bray F, Romieu I, Renehan A, Soerjomataram I (2016) Obesity and cancer: an update of the global impact. Cancer Epidemiol 41:8-15. CrossRef Medline

Atasoy D, Betley JN, Su HH, Sternson SM (2012) Deconstruction of a neural circuit for hunger. Nature 488:172-177. CrossRef Medline

Avena NM, Rada P, Hoebel BG (2008) Underweight rats have enhanced dopamine release and blunted acetylcholine response in the nucleus accumbens while bingeing on sucrose. Neuroscience 156:865-871.

Babbs RK, Sun X, Felsted J, Chouinard-Decorte F, Veldhuizen MG, Small DM (2013) Decreased caudate response to milkshake is associated with higher body mass index and greater impulsivity. Physiol Behav 121:103111. CrossRef Medline

Baimel C, Bartlett SE, Chiou LC, Lawrence AJ, Muschamp JW, Patkar O, Tung LW, Borgland SL (2015) Orexin/hypocretin role in reward: implications for opioid and other addictions. Br J Pharmacol 172:334-348. CrossRef Medline

Bakalar JL, Shank LM, Vannucci A, Radin RM, Tanofsky-Kraff M (2015) Recent advances in developmental and risk factor research on eating disorders. Curr Psychiatry Rep 17:42. CrossRef Medline

Baladi MG, Koek W, Aumann M, Velasco F, France CP (2012) Eating high fat chow enhances the locomotor-stimulating effects of cocaine in adolescent and adult female rats. Psychopharmacology (Berl) 222:447-457. CrossRef Medline

Baldo BA, Kelley AE (2007) Discrete neurochemical coding of distinguishable motivational processes: insights from nucleus accumbens control of feeding. Psychopharmacology (Berl) 191:439-459. CrossRef Medline

Baldo BA, Sadeghian K, Basso AM, Kelley AE (2002) Effects of selective dopamine D1 or D2 receptor blockade within nucleus accumbens subregions on ingestive behavior and associated motor activity. Behav Brain Res 137:165-177.

Balleine BW (2005) Neural bases of food-seeking: affect, arousal and reward in corticostriatolimbic circuits. Physiol Behav 86:717-730. CrossRef Medline 
Barbano MF, Wang HL, Morales M, Wise RA (2016) Feeding and reward are differentially induced by activating GABAergic lateral hypothalamic projections to VTA. J Neurosci 36:2975-2985. CrossRef Medline

Barson JR, Morganstern I, Leibowitz SF (2013) Complementary roles of orexin and melanin-concentrating hormone in feeding behavior. Int J Endocrinol 2013:983964. CrossRef Medline

Beckstead RM, Cruz CJ (1986) Striatal axons to the globus pallidus, entopeduncular nucleus and substantia nigra come mainly from separate cell populations in cat. Neuroscience 19:147-158. CrossRef Medline

Berridge KC (1996) Food reward: brain substrates of wanting and liking. Neurosci Biobehav Rev 20:1-25. CrossRef Medline

Berridge KC (2009) 'Liking' and 'wanting' food rewards: brain substrates and roles in eating disorders. Physiol Behav 97:537-550. CrossRef Medline

Berridge KC, Ho CY, Richard JM, DiFeliceantonio AG (2010) The tempted brain eats: pleasure and desire circuits in obesity and eating disorders. Brain Res 1350:43-64. CrossRef Medline

Berthoud HR (2004) Mind versus metabolism in the control of food intake and energy balance. Physiol Behav 81:781-793. CrossRef Medline

Bertran-Gonzalez J, Hervé D, Girault JA, Valjent E (2010) What is the degree of segregation between striatonigral and striatopallidal projections? Front Neuroanat 4:136. CrossRef Medline

Betley JN, Cao ZF, Ritola KD, Sternson SM (2013) Parallel, redundant circuit organization for homeostatic control of feeding behavior. Cell 155: 1337-1350. CrossRef Medline

Betley JN, Xu S, Cao ZF, Gong R, Magnus CJ, Yu Y, Sternson SM (2015) Neurons for hunger and thirst transmit a negative valence teaching signal. Nature 521:180-185. CrossRef Medline

Bielajew C, Shizgal P (1986) Evidence implicating descending fibers in selfstimulation of the medial forebrain bundle. J Neurosci 6:919-929. Medline

Bocklisch C, Pascoli V, Wong JC, House DR, Yvon C, de Roo M, Tan KR, Lüscher C (2013) Cocaine disinhibits dopamine neurons by potentiation of GABA transmission in the ventral tegmental area. Science 341: 1521-1525. CrossRef Medline

Bonnavion P, Mickelsen L, Fujita A, de Lecea L, Jackson AC (2016) Hubs and spokes of the lateral hypothalamus: cell types, circuits and behaviour. J Physiol. Advance online publication. Retrieved Jun. 15, 2016. doi: 10.1113/JP271946. CrossRef Medline

Borgland SL, Taha SA, Sarti F, Fields HL, Bonci A (2006) Orexin A in the VTA is critical for the induction of synaptic plasticity and behavioral sensitization to cocaine. Neuron 49:589-601. CrossRef Medline

Borgland SL, Storm E, Bonci A (2008) Orexin B/hypocretin 2 increases glutamatergic transmission to ventral tegmental area neurons. Eur J Neurosci 28:1545-1556. CrossRef Medline

Brown HD, McCutcheon JE, Cone JJ, Ragozzino ME, Roitman MF (2011) Primary food reward and reward-predictive stimuli evoke different patterns of phasic dopamine signaling throughout the striatum. Eur J Neurosci 34:1997-2006.

Brown JA, Woodworth HL, Leinninger GM (2015a) To ingest or rest? Specialized roles of lateral hypothalamic area neurons in coordinating energy balance. Front Syst Neurosci 9:9. CrossRef Medline

Brown RM, Kupchik YM, Spencer S, Garcia-Keller C, Spanswick DC, Lawrence AJ, Simonds SE, Schwartz DJ, Jordan KA, Jhou TC, Kalivas PW (2015b) Addiction-like synaptic impairments in diet-induced obesity. Biol Psychiatry. Advance online publication. Retrieved Dec. 2, 2015. doi: 10.1016/j.biopsych.2015.11.019. CrossRef Medline

Burdakov D, Gerasimenko O, Verkhratsky A (2005) Physiological changes in glucose differentially modulate the excitability of hypothalamic melanin-concentrating hormone and orexin neurons in situ. J Neurosci 25:2429-2433. CrossRef Medline

Cai XJ, Widdowson PS, Harrold J, Wilson S, Buckingham RE, Arch JR, Tadayyon M, Clapham JC, Wilding J, Williams G (1999) Hypothalamic orexin expression: modulation by blood glucose and feeding. Diabetes 48:2132-2137. CrossRef Medline

Cai XJ, Evans ML, Lister CA, Leslie RA, Arch JR, Wilson S, Williams G (2001) Hypoglycemia activates orexin neurons and selectively increases hypothalamic orexin-B levels: responses inhibited by feeding and possibly mediated by the nucleus of the solitary tract. Diabetes 50:105-112. CrossRef Medline

Cannon CM, Palmiter RD (2003) Reward without dopamine. J Neurosci 23:10827-10831. Medline
Cansell C, Castel J, Denis RG, Rouch C, Delbes AS, Martinez S, Mestivier D, Finan B, Maldonado-Aviles JG, Rijnsburger M, Tschöp MH, DiLeone RJ, Eckel RH, la Fleur SE, Magnan C, Hnasko TS, Luquet S (2014) Dietary triglycerides act on mesolimbic structures to regulate the rewarding and motivational aspects of feeding. Mol Psychiatry 19:1095-1105. CrossRef Medline

Cason AM, Aston-Jones G (2013) Attenuation of saccharin-seeking in rats by orexin/hypocretin receptor 1 antagonist. Psychopharmacology (Berl) 228:499-507. CrossRef Medline

Castro DC, Berridge KC (2014) Opioid hedonic hotspot in nucleus accumbens shell: $\mu, \delta$, and $\kappa$ maps for enhancement of sweetness "liking" and "wanting." J Neurosci 34:4239-4250. CrossRef

Castro DC, Cole SL, Berridge KC (2015) Lateral hypothalamus, nucleus accumbens, and ventral pallidum roles in eating and hunger: interactions between homeostatic and reward circuitry. Front Syst Neurosci 9:90. CrossRef Medline

Cawley J (2016) Does anything work to reduce obesity? (Yes, modestly). J Health Polit Policy Law 41:463-472. CrossRef Medline

Chee MJ, Arrigoni E, Maratos-Flier E (2015) Melanin-concentrating hormone neurons release glutamate for feedforward inhibition of the lateral septum. J Neurosci 35:3644-3651. CrossRef Medline

Chen M, Woods SC, Porte D Jr (1975) Effect of cerebral intraventricular insulin on pancreatic insulin secretion in the dog. Diabetes 24:910-914. CrossRef Medline

Chen Y, Lin YC, Kuo TW, Knight ZA (2015) Sensory detection of food rapidly modulates arcuate feeding circuits. Cell 160:829-841. CrossRef Medline

Chua SC Jr, Chung WK, Wu-Peng XS, Zhang Y, Liu SM, Tartaglia L, Leibel RL (1996) Phenotypes of mouse diabetes and rat fatty due to mutations in the OB (leptin) receptor. Science 271:994-996. CrossRef Medline

Cone JJ, Roitman JD, Roitman MF (2015) Ghrelin regulates phasic dopamine and nucleus accumbens signaling evoked by food-predictive stimuli. J Neurochem 133:844-856.

Cork SC, Richards JE, Holt MK, Gribble FM, Reimann F, Trapp S (2015) Distribution and characterisation of Glucagon-like peptide-1 receptor expressing cells in the mouse brain. Mol Metab 4:718-731. CrossRef Medline

Counotte DS, Schiefer C, Shaham Y, O’Donnell P (2014) Time-dependent decreases in nucleus accumbens AMPA/NMDA ratio and incubation of sucrose craving in adolescent and adult rats. Psychopharmacology (Berl) 231:1675-1684. CrossRef Medline

Cowley MA, Smith RG, Diano S, Tschöp M, Pronchuk N, Grove KL, Strasburger CJ, Bidlingmaier M, Esterman M, Heiman ML, Garcia-Segura LM, Nillni EA, Mendez P, Low MJ, Sotonyi P, Friedman JM, Liu H, Pinto S, Colmers WF, Cone RD, et al. (2003) The distribution and mechanism of action of ghrelin in the CNS demonstrates a novel hypothalamic circuit regulating energy homeostasis. Neuron 37:649-661. CrossRef Medline

Cowley MA, Smart JL, Rubinstein M, Cerdán MG, Diano S, Horvath TL, Cone RD, Low MJ (2001) Leptin activates anorexigenic POMC neurons through a neural network in the arcuate nucleus. Nature 411:480-484. CrossRef Medline

Csajbók ÉA, Tamás G (2016) Cerebral cortex: a target and source of insulin? Diabetologia 59:1609-1615. CrossRef Medline

Cui G, Jun SB, Jin X, Pham MD, Vogel SS, Lovinger DM, Costa RM (2013) Concurrent activation of striatal direct and indirect pathways during action initiation. Nature 494:238-242. CrossRef Medline

Dailey MJ, Moran TH, Holland PC, Johnson AW (2016) The antagonism of ghrelin alters the appetitive response to learned cues associated with food. Behav Brain Res 303:191-200. CrossRef Medline

de Araujo IE (2016) Circuit organization of sugar reinforcement. Physiol Behav 164:473-477. CrossRef Medline

de Lecea L, Kilduff TS, Peyron C, Gao X, Foye PE, Danielson PE, Fukuhara C, Battenberg EL, Gautvik VT, Bartlett FS 2nd, Frankel WN, van den Pol AN, Bloom FE, Gautvik KM, Sutcliffe JG (1998) The hypocretins: hypothalamus-specific peptides with neuroexcitatory activity. Proc Natl Acad Sci U S A 95:322-327. CrossRef Medline

Delgado JM, Anand BK (1953) Increase of food intake induced by electrical stimulation of the lateral hypothalamus. Am J Physiol 172:162-168. Medline

De Matteis R, Cinti S (1998) Ultrastructural immunolocalization of leptin receptor in mouse brain. Neuroendocrinology 68:412-419. CrossRef Medline 
Demos KE, Heatherton TF, Kelley WM (2012) Individual differences in nucleus accumbens activity to food and sexual images predict weight gain and sexual behavior. J Neurosci 32:5549-5552. CrossRef Medline

Dodd GT, Williams SR, Luckman SM (2010) Functional magnetic resonance imaging and c-Fos mapping in rats following a glucoprivic dose of 2-deoxy-D-glucose. J Neurochem 113:1123-1132. CrossRef Medline

Domingos AI, Vaynshteyn J, Voss HU, Ren X, Gradinaru V, Zang F, Deisseroth K, de Araujo IE, Friedman J (2011) Leptin regulates the reward value of nutrient. Nat Neurosci 14:1562-1568. CrossRef Medline

Egecioglu E, Jerlhag E, Salomé N, Skibicka KP, Haage D, Bohlooly YM, Andersson D, Bjursell M, Perrissoud D, Engel JA, Dickson SL (2010) Ghrelin increases intake of rewarding food in rodents. Addict Biol 15:304-311. CrossRef Medline

Elias CF, Aschkenasi C, Lee C, Kelly J, Ahima RS, Bjorbaek C, Flier JS, Saper CB, Elmquist JK (1999) Leptin differentially regulates NPY and POMC neurons projecting to the lateral hypothalamic area. Neuron 23:775-786. CrossRef Medline

Eny KM, Wolever TM, Fontaine-Bisson B, El-Sohemy A (2008) Genetic variant in the glucose transporter type 2 is associated with higher intakes of sugars in two distinct populations. Physiol Genomics 33:355-360. CrossRef Medline

Fadel JR, Jolivalt CG, Reagan LP (2013) Food for thought: the role of appetitive peptides in age-related cognitive decline. Ageing Res Rev 12:764776. CrossRef Medline

Felsted JA, Ren X, Chouinard-Decorte F, Small DM (2010) Genetically determined differences in brain response to a primary food reward. J Neurosci 30:2428-2432. CrossRef Medline

Fields HL, Hjelmstad GO, Margolis EB, Nicola SM (2007) Ventral tegmental area neurons in learned appetitive behavior and positive reinforcement. Annu Rev Neurosci 30:289-316. CrossRef Medline

Figlewicz DP, Evans SB, Murphy J, Hoen M, Baskin DG (2003) Expression of receptors for insulin and leptin in the ventral tegmental area/substantia nigra (VTA/SN) of the rat. Brain Res 964:107-115. CrossRef Medline

Fioramonti X, Contié S, Song Z, Routh VH, Lorsignol A, Pénicaud L (2007) Characterization of glucosensing neuron subpopulations in the arcuate nucleus: integration in neuropeptide $\mathrm{Y}$ and pro-opiomelanocortin networks? Diabetes 56:1219-1227. CrossRef Medline

Franklin KB, Paxinos G (2008) The mouse brain in stereotaxic coordinates. San Diego: Academic.

Fulton S (2010) Appetite and reward. Front Neuroendocrinol 31:85-103. CrossRef Medline

Garfield AS, Li C, Madara JC, Shah BP, Webber E, Steger JS, Campbell JN, Gavrilova O, Lee CE, Olson DP, Elmquist JK, Tannous BA, Krashes MJ, Lowell BB (2015) A neural basis for melanocortin-4 receptor-regulated appetite. Nat Neurosci 18:863-871. CrossRef Medline

Geiger BM, Haburcak M, Avena NM, Moyer MC, Hoebel BG, Pothos EN (2009) Deficits of mesolimbic dopamine neurotransmission in rat dietary obesity. Neuroscience 159:1193-1199. CrossRef Medline

Gerfen CR, Engber TM, Mahan LC, Susel Z, Chase TN, Monsma FJ Jr, Sibley DR (1990) D1 and D2 dopamine receptor-regulated gene expression of striatonigral and striatopallidal neurons. Science 250:1429-1432. CrossRef Medline

Gittis AH, Kreitzer AC (2012) Striatal microcircuitry and movement disorders. Trends Neurosci 35:557-564. CrossRef Medline

Gratton A, Wise RA (1988) Comparisons of refractory periods for medial forebrain bundle fibers subserving stimulation-induced feeding and brain stimulation reward: a psychophysical study. Brain Res 438:256263. CrossRef Medline

Hahn JD, Swanson LW (2010) Distinct patterns of neuronal inputs and outputs of the juxtaparaventricular and suprafornical regions of the lateral hypothalamic area in the male rat. Brain Res Rev 64:14-103. CrossRef Medline

Haight JL, Fraser KM, Akil H, Flagel SB (2015) Lesions of the paraventricular nucleus of the thalamus differentially affect sign- and goaltracking conditioned responses. Eur J Neurosci 42:2478-2488. CrossRef Medline

Halaas JL, Gajiwala KS, Maffei M, Cohen SL, Chait BT, Rabinowitz D, Lallone RL, Burley SK, Friedman JM (1995) Weight-reducing effects of the plasma protein encoded by the obese gene. Science 269:543-546. CrossRef Medline

Hanlon EC, Baldo BA, Sadeghian K, Kelley AE (2004) Increases in food intake or food-seeking behavior induced by GABAergic, opioid, or dopaminer- gic stimulation of the nucleus accumbens: is it hunger? Psychopharm 172:241-247.

Harris GC, Aston-Jones G (2006) Arousal and reward: a dichotomy in orexin function. Trends Neurosci 29:571-577. CrossRef Medline

Harris GC, Wimmer M, Aston-Jones G (2005) A role for lateral hypothalamic orexin neurons in reward seeking. Nature 437:556-559. CrossRef Medline

Harris GC, Wimmer M, Randall-Thompson JF, Aston-Jones G (2007) Lateral hypothalamic orexin neurons are critically involved in learning to associate an environment with morphine reward. Behav Brain Res 183: 43-51. CrossRef Medline

Hart S, Franklin RC, Russell J, Abraham S (2013) A review of feeding methods used in the treatment of anorexia nervosa. J Eat Disord 1:36. CrossRef Medline

Hayes MR, Schmidt HD (2016) GLP-1 influences food and drug reward. Curr Opin Behav Sci 9:66-70. CrossRef Medline

Hetherington AW, Ranson SW (1940) Hypothalamic lesions and adiposity in the rat. Anat Rec 78:149-172. CrossRef Medline

Hnasko TS, Perez FA, Scouras AD, Stoll EA, Gale SD, Luquet S, Phillips PE, Kremer EJ, Palmiter RD (2006) Cre recombinase-mediated restoration of nigrostriatal dopamine in dopamine-deficient mice reverses hypophagia and bradykinesia. Proc Natl Acad Sci U S A 103:8858-8863. CrossRef Medline

Hommel JD, Trinko R, Sears RM, Georgescu D, Liu ZW, Gao XB, Thurmon JJ, Marinelli M, DiLeone RJ (2006) Leptin receptor signaling in midbrain dopamine neurons regulates feeding. Neuron 51:801-810. CrossRef Medline

Hruby A, Manson JE, Qi L, Malik VS, Rimm EB, Sun Q, Willett WC, Hu FB (2016) Determinants and consequences of obesity. Am J Public Health 106:1656-1662. CrossRef Medline

Hryhorczuk C, Florea M, Rodaros D, Poirier I, Daneault C, Des Rosiers C, Arvanitogiannis A, Alquier T, Fulton S (2016) Dampened mesolimbic dopamine function and signaling by saturated but not monounsaturated dietary lipids. Neuropsychopharmacology 41:811-821. CrossRef Medline

Jego S, Glasgow SD, Herrera CG, Ekstrand M, Reed SJ, Boyce R, Friedman J, Burdakov D, Adamantidis AR (2013) Optogenetic identification of a rapid eye movement sleep modulatory circuit in the hypothalamus. Nat Neurosci 16:1637-1643. CrossRef Medline

Jennings JH, Ung RL, Resendez SL, Stamatakis AM, Taylor JG, Huang J, Veleta K, Kantak PA, Aita M, Shilling-Scrivo K, Ramakrishnan C, Deisseroth K, Otte S, Stuber GD (2015) Visualizing hypothalamic network dynamics for appetitive and consummatory behaviors. Cell 160:516-527. CrossRef Medline

Johnson PM, Kenny PJ (2010) Dopamine D2 receptors in addiction-like reward dysfunction and compulsive eating in obese rats. Nat Neurosci 13:635-641. CrossRef Medline

Karnani MM, Szabó G, Erdélyi F, Burdakov D (2013) Lateral hypothalamic GAD65 neurons are spontaneously firing and distinct from orexin- and melanin-concentrating hormone neurons. J Physiol 591:933-953. CrossRef Medline

Kaye WH, Wierenga CE, Bailer UF, Simmons AN, Bischoff-Grethe A (2013) Nothing tastes as good as skinny feels: the neurobiology of anorexia nervosa. Trends Neurosci 36:110-120. CrossRef Medline

Kelley AE, Baldo BA, Pratt WE (2005) A proposed hypothalamic-thalamicstriatal axis for the integration of energy balance, arousal, and food reward. J Comp Neurol 493:72-85. CrossRef Medline

Kempadoo KA, Tourino C, Cho SL, Magnani F, Leinninger GM, Stuber GD, Zhang F, Myers MG, Deisseroth K, de Lecea L, Bonci A (2013) Hypothalamic neurotensin projections promote reward by enhancing glutamate transmission in the VTA. J Neurosci 33:7618-7626. CrossRef Medline

Kenny PJ, Voren G, Johnson PM (2013) Dopamine D2 receptors and striatopallidal transmission in addiction and obesity. Curr Opin Neurobiol 23:535-538. CrossRef Medline

Kim CK, Yang SJ, Pichamoorthy N, Young NP, Kauvar I, Jennings JH, Lerner TN, Berndt A, Lee SY, Ramakrishnan C, Davidson TJ, Inoue M, Bito H, Deisseroth K (2016) Simultaneous fast measurement of circuit dynamics at multiple sites across the mammalian brain. Nat Methods 13:325328. CrossRef Medline

King BM (2006) The rise, fall, and resurrection of the ventromedial hypothalamus in the regulation of feeding behavior and body weight. Physiol Behav 87:221-244. CrossRef Medline 
King CM, Hentges ST (2011) Relative number and distribution of murine hypothalamic proopiomelanocortin neurons innervating distinct target sites. PLoS One 6:e25864. CrossRef Medline

King SJ, Isaacs AM, O'Farrell E, Abizaid A (2011) Motivation to obtain preferred foods is enhanced by ghrelin in the ventral tegmental area. Horm Behav 60:572-580. CrossRef Medline

Kirouac GJ (2015) Placing the paraventricular nucleus of the thalamus within the brain circuits that control behavior. Neurosci Biobehav Rev 56:315-329. CrossRef Medline

Könner AC, Janoschek R, Plum L, Jordan SD, Rother E, Ma X, Xu C, Enriori P, Hampel B, Barsh GS, Kahn CR, Cowley MA, Ashcroft FM, Brüning JC (2007) Insulin action in AGRP-expressing neurons is required for suppression of hepatic glucose production. Cell Metab 5:438-449. CrossRef Medline

Krashes MJ, Koda S, Ye C, Rogan SC, Adams AC, Cusher DS, Maratos-Flier E, Roth BL, Lowell BB (2011) Rapid, reversible activation of AGRP neurons drives feeding behavior in mice. J Clin Invest 121:1424-1428. CrossRef Medline

Krashes MJ, Shah BP, Madara JC, Olson DP, Strochlic DE, Garfield AS, Vong L, Pei H, Watabe-Uchida M, Uchida N, Liberles SD, Lowell BB (2014) An excitatory paraventricular nucleus to AGRP neuron circuit that drives hunger. Nature 507:238-242. CrossRef Medline

Kravitz AV, Freeze BS, Parker PR, Kay K, Thwin MT, Deisseroth K, Kreitzer AC (2010) Regulation of parkinsonian motor behaviours by optogenetic control of basal ganglia circuitry. Nature 466:622-626. CrossRef Medline

Kravitz AV, Tye LD, Kreitzer AC (2012) Distinct roles for direct and indirect pathway striatal neurons in reinforcement. Nat Neurosci 15:816-818. CrossRef Medline

Kroemer NB, Small DM (2016) Fuel not fun: reinterpreting attenuated brain responses to reward in obesity. Physiol Behav 162:37-45. CrossRef Medline

Kullmann S, Frank S, Heni M, Ketterer C, Veit R, Häring HU, Fritsche A, Preissl H (2013) Intranasal insulin modulates intrinsic reward and prefrontal circuitry of the human brain in lean women. Neuroendocrinology 97:176-182. CrossRef Medline

Kupchik YM, Brown RM, Heinsbroek JA, Lobo MK, Schwartz DJ, Kalivas PW (2015) Coding the direct/indirect pathways by D1 and D2 receptors is not valid for accumbens projections. Nat Neurosci 18:1230-1232. CrossRef Medline

Labouèbe G, Liu S, Dias C, Zou H, Wong JC, Karunakaran S, Clee SM, Phillips AG, Boutrel B, Borgland SL (2013) Insulin induces long-term depression of ventral tegmental area dopamine neurons via endocannabinoids. Nat Neurosci 16:300-308. CrossRef Medline

Labouèbe G, Boutrel B, Tarussio D, Thorens B (2016) Glucose-responsive neurons of the paraventricular thalamus control sucrose-seeking behavior. Nat Neurosci 19:999-1002. CrossRef Medline

Lamy CM, Sanno H, Labouèbe G, Picard A, Magnan C, Chatton JY, Thorens B (2014) Hypoglycemia-activated GLUT2 neurons of the nucleus tractus solitarius stimulate vagal activity and glucagon secretion. Cell Metab 19:527-538. CrossRef Medline

Langeveld M, DeVries JH (2015) The long-term effect of energy restricted diets for treating obesity. Obesity (Silver Spring) 23:1529-1538. CrossRef Medline

Lee JS, Lee EY, Lee HS (2015) Hypothalamic, feeding/arousal-related peptidergic projections to the paraventricular thalamic nucleus in the rat. Brain Res 1598:97-113. CrossRef Medline

Leinninger GM, Opland DM, Jo YH, Faouzi M, Christensen L, Cappellucci LA, Rhodes CJ, Gnegy ME, Becker JB, Pothos EN, Seasholtz AF, Thompson RC, Myers MG Jr (2011) Leptin action via neurotensin neurons controls orexin, the mesolimbic dopamine system and energy balance. Cell Metab 14:313-323. CrossRef Medline

Lim BK, Huang KW, Grueter BA, Rothwell PE, Malenka RC (2012) Anhedonia requires MC4R-mediated synaptic adaptations in nucleus accumbens. Nature 487:183-189. CrossRef Medline

Lindblom J, Opmane B, Mutulis F, Mutule I, Petrovska R, Klusa V, Bergström L, Wikberg JE (2001) The MC4 receptor mediates alpha-MSH induced release of nucleus accumbens dopamine. Neuroreport 12:2155-2158. CrossRef Medline

Liu S, Labouèbe G, Karunakaran S, Clee SM, Borgland SL (2013) Effect of insulin on excitatory synaptic transmission onto dopamine neurons of the ventral tegmental area in a mouse model of hyperinsulinemia. Nutr Diabetes 3:e97. CrossRef Medline

Liu S, Globa AK, Mills F, Naef L, Qiao M, Bamji SX, Borgland SL (2016) Consumption of palatable food primes food approach behavior by rapidly increasing synaptic density in the VTA. Proc Natl Acad Sci U S A 113:2520-2525. CrossRef Medline

Loweth JA, Tseng KY, Wolf ME (2014) Adaptations in AMPA receptor transmission in the nucleus accumbens contributing to incubation of cocaine craving. Neuropharmacology 76:287-300. CrossRef Medline

Lüscher C (2016) The emergence of a circuit model for addiction. Annu Rev Neurosci 39:257-276. CrossRef Medline

Mandelblat-Cerf Y, Ramesh RN, Burgess CR, Patella P, Yang Z, Lowell BB, Andermann ML (2015) Arcuate hypothalamic AGRP and putative POMC neurons show opposite changes in spiking across multiple timescales. Elife 4:351. CrossRef Medline

Marston OJ, Hurst P, Evans ML, Burdakov DI, Heisler LK (2011) Neuropeptide $Y$ cells represent a distinct glucose-sensing population in the lateral hypothalamus. Endocrinology 152:4046-4052. CrossRef Medline

Martin-Fardon R, Boutrel B (2012) Orexin/hypocretin (Orx/Hcrt) transmission and drug-seeking behavior: is the paraventricular nucleus of the thalamus (PVT) part of the drug seeking circuitry? Front Behav Neurosci 6:75. CrossRef Medline

Matzeu A, Zamora-Martinez ER, Martin-Fardon R (2014) The paraventricular nucleus of the thalamus is recruited by both natural rewards and drugs of abuse: recent evidence of a pivotal role for orexin/hypocretin signaling in this thalamic nucleus in drug-seeking behavior. Front Behav Neurosci 8:117. CrossRef Medline

Meister B (2007) Neurotransmitters in key neurons of the hypothalamus that regulate feeding behavior and body weight. Physiol Behav 92:263271. CrossRef Medline

Meredith GE, Baldo BA, Andrezjewski ME, Kelley AE (2008) The structural basis for mapping behavior onto the ventral striatum and its subdivisions. Brain Struct Funct 213:17-27. CrossRef Medline

Mogenson GJ, Jones DL, Yim CY (1980) From motivation to action: functional interface between the limbic system and the motor system. Prog Neurobiol 14:69-97. CrossRef Medline

Nair-Roberts RG, Chatelain-Badie SD, Benson E, White-Cooper H, Bolam JP, Ungless MA (2008) Stereological estimates of dopaminergic, GABAergic and glutamatergic neurons in the ventral tegmental area, substantia nigra and retrorubral field in the rat. Neuroscience 152:10241031. CrossRef Medline

Nakazato M, Murakami N, Date Y, Kojima M, Matsuo H, Kangawa K, Matsukura S (2001) A role for ghrelin in the central regulation of feeding. Nature 409:194-198. CrossRef Medline

Naleid AM, Grace MK, Cummings DE, Levine AS (2005) Ghrelin induces feeding in the mesolimbic reward pathway between the ventral tegmental area and the nucleus accumbens. Peptides 26:2274-2279. CrossRef Medline

Narayanan NS, Guarnieri DJ, DiLeone RJ (2010) Metabolic hormones, dopamine circuits, and feeding. Front Neuroendocrinol 31:104-112. CrossRef Medline

Nieh EH, Matthews GA, Allsop SA, Presbrey KN, Leppla CA, Wichmann R, Neve R, Wildes CP, Tye KM (2015) Decoding neural circuits that control compulsive sucrose seeking. Cell 160:528-541. CrossRef Medline

Nieh EH, Vander Weele CM, Matthews GA, Presbrey KN, Wichmann R, Leppla CA, Izadmehr EM, Tye KM (2016) Inhibitory input from the lateral hypothalamus to the ventral tegmental area disinhibits dopamine neurons and promotes behavioral activation. Neuron 90:1286-1298. CrossRef Medline

Nowend KL, Arizzi M, Carlson BB, Salamone JD (2001) D1 or D2 antagonism in nucleus accumbens core or dorsomedial shell suppresses lever pressing for food but leads to compensatory increases in chow consumption. Pharmacol Biochem Behav 69:373-382.

Obici S, Feng Z, Karkanias G, Baskin DG, Rossetti L (2002) Decreasing hypothalamic insulin receptors causes hyperphagia and insulin resistance in rats. Nat Neurosci 5:566-572. CrossRef Medline

O'Connor RM, Kenny PJ (2016) Role of striatal dopamine signaling in compulsive eating associated with obesity. Curr Opin Behav Sci 9: 152-157.

O'Connor EC, Kremer Y, Lefort S, Harada M, Pascoli V, Rohner C, Lüscher C (2015) Accumbal D1R neurons projecting to lateral hypothalamus authorize feeding. Neuron 88:553-564. CrossRef Medline

Oginsky MF, Goforth PB, Nobile CW, Lopez-Santiago L, Ferrario CR (2016) 
Eating "junk-food" produces rapid and long-lasting increases in NAc CP-AMPA receptors; implications for enhanced cue-induced motivation and food addiction. Neuropsychopharmacology. Advance online publication. Retrieved Aug. 24, 2016. doi: 10.1038/npp.2016.111. CrossRef Medline

O'Neill S, O'Driscoll L (2015) Metabolic syndrome: a closer look at the growing epidemic and its associated pathologies. Obes Rev 16:1-12. CrossRef Medline

Opland DM, Leinninger GM, Myers MG Jr (2010) Modulation of the mesolimbic dopamine system by leptin. Brain Res 1350:65-70. CrossRef Medline

Opland D, Sutton A, Woodworth H, Brown J, Bugescu R, Garcia A, Christensen L, Rhodes C, Myers M Jr, Leinninger G (2013) Loss of neurotensin receptor-1 disrupts the control of the mesolimbic dopamine system by leptin and promotes hedonic feeding and obesity. Mol Metab 2:423-434. CrossRef Medline

Palmiter RD (2007) Is dopamine a physiologically relevant mediator of feeding behavior? Trends Neurosci 30:375-381. CrossRef Medline

Palmiter RD (2008) Dopamine signaling in the dorsal striatum is essential for motivated behaviors: lessons from dopamine-deficient mice. Ann N Y Acad Sci 1129:35-46. CrossRef Medline

Pandit R, la Fleur SE, Adan RA (2013) The role of melanocortins and neuropeptide Y in food reward. Eur J Pharmacol 719:208-214. CrossRef Medline

Papadopoulos FC, Ekbom A, Brandt L, Ekselius L (2009) Excess mortality, causes of death and prognostic factors in anorexia nervosa. Br J Psychiatry 194:10-17. CrossRef Medline

Parsons MP, Li S, Kirouac GJ (2006) The paraventricular nucleus of the thalamus as an interface between the orexin and CART peptides and the shell of the nucleus accumbens. Synapse 59:480-490. CrossRef Medline

Parsons MP, Li S, Kirouac GJ (2007) Functional and anatomical connection between the paraventricular nucleus of the thalamus and dopamine fibers of the nucleus accumbens. J Comp Neurol 500:1050-1063. CrossRef Medline

Pelleymounter MA, Cullen MJ, Baker MB, Hecht R, Winters D, Boone T, Collins F (1995) Effects of the obese gene product on body weight regulation in ob/ob mice. Science 269:540-543. CrossRef Medline

Perry ML, Leinninger GM, Chen R, Luderman KD, Yang H, Gnegy ME, Myers MG Jr, Kennedy RT (2010) Leptin promotes dopamine transporter and tyrosine hydroxylase activity in the nucleus accumbens of Sprague-Dawley rats. J Neurochem 114:666-674. CrossRef Medline

Petrovich GD (2013) Forebrain networks and the control of feeding by environmental learned cues. Physiol Behav 121:10-18. CrossRef Medline

Qu D, Ludwig DS, Gammeltoft S, Piper M, Pelleymounter MA, Cullen MJ, Mathes WF, Przypek R, Kanarek R, Maratos-Flier E (1996) A role for melanin-concentrating hormone in the central regulation of feeding behaviour. Nature 380:243-247. CrossRef Medline

Renier N, Adams EL, Kirst C, Wu Z, Azevedo R, Kohl J, Autry AE, Kadiri L, Umadevi Venkataraju K, Zhou Y, Wang VX, Tang CY, Olsen O, Dulac C, Osten P, Tessier-Lavigne M (2016) Mapping of brain activity by automated volume analysis of immediate early genes. Cell 165:1789-1802. CrossRef Medline

Robinson MJ, Burghardt PR, Patterson CM, Nobile CW, Akil H, Watson SJ, Berridge KC, Ferrario CR (2015) Individual differences in cue-induced motivation and striatal systems in rats susceptible to diet-induced obesity. Neuropsychopharmacology 40:2113-2123. CrossRef Medline

Rothemund Y, Preuschhof C, Bohner G, Bauknecht HC, Klingebiel R, Flor H, Klapp BF (2007) Differential activation of the dorsal striatum by highcalorie visual food stimuli in obese individuals. Neuroimage 37:410-421. CrossRef Medline

Sakurai T, Amemiya A, Ishii M, Matsuzaki I, Chemelli RM, Tanaka H, Williams SC, Richardson JA, Kozlowski GP, Wilson S, Arch JR, Buckingham RE, Haynes AC, Carr SA, Annan RS, McNulty DE, Liu WS, Terrett JA, Elshourbagy NA, Bergsma DJ, et al. (1998) Orexins and orexin receptors: a family of hypothalamic neuropeptides and G protein-coupled receptors that regulate feeding behavior. Cell 92:573-585. CrossRef Medline

Salamone JD, Correa M, Mingote S, Weber SM (2003) Nucleus accumbens dopamine and the regulation of effort in food-seeking behavior: implications for studies of natural motivation, psychiatry, and drug abuse. J Pharmacol Exp Ther 305:1-8. CrossRef Medline

Salamone JD, Wisniecki A, Carlson BB, Correa M (2001) Nucleus accumbens dopamine depletions make animals highly sensitive to high fixed ratio requirements but do not impair primary food reinforcement. Neuroscience 105:863-870.

Schöne C, Burdakov D (2012) Glutamate and GABA as rapid effectors of hypothalamic "peptidergic" neurons. Front Behav Neurosci 6:81. CrossRef Medline

Schultz W, Dayan P, Montague PR (1997) A neural substrate of prediction and reward. Science 275:1593-1599. CrossRef Medline

Schwartz MW, Sipols AJ, Marks JL, Sanacora G, White JD, Scheurink A, Kahn SE, Baskin DG, Woods SC, Figlewicz DP (1992) Inhibition of hypothalamic neuropeptide Y gene expression by insulin. Endocrinology 130: 3608-3616. CrossRef Medline

Sesack SR, Grace AA (2010) Cortico-basal ganglia reward network: microcircuitry. Neuropsychopharmacology 35:27-47. CrossRef Medline

Sheng Z, Santiago AM, Thomas MP, Routh VH (2014) Metabolic regulation of lateral hypothalamic glucose-inhibited orexin neurons may influence midbrain reward neurocircuitry. Mol Cell Neurosci 62:30-41. CrossRef Medline

Skibicka KP, Hansson C, Alvarez-Crespo M, Friberg PA, Dickson SL (2011) Ghrelin directly targets the ventral tegmental area to increase food motivation. Neuroscience 180:129-137. CrossRef Medline

Small DM (2009) Individual differences in the neurophysiology of reward and the obesity epidemic. Int J Obes (Lond) 33 [Suppl 2]:S44-S48.

Smink FR, van Hoeken D, Hoek HW (2012) Epidemiology of eating disorders: incidence, prevalence and mortality rates. Curr Psychiatry Rep 14: 406-414. CrossRef Medline

Sotak BN, Hnasko TS, Robinson S, Kremer EJ, Palmiter RD (2005) Dysregulation of dopamine signaling in the dorsal striatum inhibits feeding. Brain Res 1061:88-96. CrossRef Medline

Stamatakis AM, Van Swieten M, Basiri ML, Blair GA, Kantak P, Stuber GD (2016) Lateral hypothalamic area glutamatergic neurons and their projections to the lateral habenula regulate feeding and reward. J Neurosci 36:302-311. CrossRef Medline

Steculorum SM, Ruud J, Karakasilioti I, Backes H, Engström Ruud L, Timper K, Hess ME, Tsaousidou E, Mauer J, Vogt MC, Paeger L, Bremser S, Klein AC, Morgan DA, Frommolt P, Brinkkötter PT, Hammerschmidt P, Benzing T, Rahmouni K, Wunderlich FT, et al. (2016) AGRP neurons control systemic insulin sensitivity via myostatin expression in brown adipose tissue. Cell 165:125-138. CrossRef Medline

Sternson SM (2013) Hypothalamic survival circuits: blueprints for purposive behaviors. Neuron 77:810-824. CrossRef Medline

Stice E, Marti CN, Spoor S, Presnell K, Shaw H (2008a) Dissonance and healthy weight eating disorder prevention programs: long-term effects from a randomized efficacy trial. J Consult Clin Psychol 76:329-340. CrossRef Medline

Stice E, Spoor S, Bohon C, Small DM (2008b) Relation between obesity and blunted striatal response to food is moderated by TaqIA A1 allele. Science 322:449-452. CrossRef Medline

Stice E, Spoor S, Ng J, Zald DH (2009) Relation of obesity to consummatory and anticipatory food reward. Physiol Behav 97:551-560. CrossRef Medline

Stice E, Yokum S, Blum K, Bohon C (2010) Weight gain is associated with reduced striatal response to palatable food. J Neurosci 30:13105-13109. CrossRef Medline

Stice E, Figlewicz DP, Gosnell BA, Levine AS, Pratt WE (2013) The contribution of brain reward circuits to the obesity epidemic. Neurosci Biobehav Rev 37:2047-2058. CrossRef Medline

Stice E, Burger KS, Yokum S (2015) Reward region responsivity predicts future weight gain and moderating effects of the TaqIA allele. J Neurosci 35:10316-10324. CrossRef Medline

Stoeckel LE, Weller RE, Cook EW 3rd, Twieg DB, Knowlton RC, Cox JE (2008) Widespread reward-system activation in obese women in response to pictures of high-calorie foods. Neuroimage 41:636-647. CrossRef Medline

Stouffer MA, Woods CA, Patel JC, Lee CR, Witkovsky P, Bao L, Machold RP, Jones KT, de Vaca SC, Reith ME, Carr KD, Rice ME (2015) Insulin enhances striatal dopamine release by activating cholinergic interneurons and thereby signals reward. Nat Commun 6:8543. CrossRef Medline

Stratford TR, Wirtshafter D (2013) Injections of muscimol into the paraventricular thalamic nucleus, but not mediodorsal thalamic nuclei, induce feeding in rats. Brain Res 1490:128-133. CrossRef Medline

Sutton AK, Myers MG Jr, Olson DP (2016) The role of PVH circuits in 
leptin action and energy balance. Annu Rev Physiol 78:207-221. CrossRef Medline

Szczypka MS, Kwok K, Brot MD, Marck BT, Matsumoto AM, Donahue BA, Palmiter RD (2001) Dopamine production in the caudate putamen restores feeding in dopamine-deficient mice. Neuron 30:819-828. CrossRef Medline

Taha SA, Fields HL (2005) Encoding of palatability and appetitive behaviors by distinct neuronal populations in the nucleus accumbens. J Neurosci 25:1193-1202. CrossRef Medline

Tarussio D, Metref S, Seyer P, Mounien L, Vallois D, Magnan C, Foretz M, Thorens B (2014) Nervous glucose sensing regulates postnatal $\beta$ cell proliferation and glucose homeostasis. J Clin Invest 124:413-424. CrossRef Medline

Tellez LA, Han W, Zhang X, Ferreira TL, Perez IO, Shammah-Lagnado SJ, van den Pol AN, de Araujo IE (2016) Separate circuitries encode the hedonic and nutritional values of sugar. Nat Neurosci 19:465-470. CrossRef Medline

Tepper JM, Bolam JP (2004) Functional diversity and specificity of neostriatal interneurons. Curr Opin Neurobiol 14:685-692. CrossRef Medline

Terrier J, Lüscher C, Pascoli V (2016) Cell type specific insertion of GluA2lacking AMPARs with cocaine exposure leading to sensitization, cueinduced seeking, and incubation of craving. Neuropsychopharmacology 41:1779-1789. CrossRef Medline

Thanos PK, Michaelides M, Piyis YK, Wang GJ, Volkow ND (2008) Food restriction markedly increases dopamine D2 receptor (D2R) in a rat model of obesity as assessed with in-vivo muPET imaging $\left(\left[{ }^{11} \mathrm{C}\right]\right.$ raclopride) and in-vitro $\left(\left[{ }^{3} \mathrm{H}\right]\right.$ spiperone) autoradiography. Synapse $62: 50-$ 61. CrossRef Medline

Thompson JL, Borgland SL (2011) A role for hypocretin/orexin in motivation. Behav Brain Res 217:446-453. CrossRef Medline

Timofeeva E, Richard D (2001) Activation of the central nervous system in obese Zucker rats during food deprivation. J Comp Neurol 441:71-89. CrossRef Medline

Tomasi D, Volkow ND (2013) Striatocortical pathway dysfunction in addiction and obesity: differences and similarities. Crit Rev Biochem Mol Biol 48:1-19. CrossRef Medline

Tschöp M, Smiley DL, Heiman ML (2000) Ghrelin induces adiposity in rodents. Nature 407:908-913. CrossRef Medline

Tukey DS, Ferreira JM, Antoine SO, D'amour JA, Ninan I, Cabeza de Vaca S, Incontro S, Wincott C, Horwitz JK, Hartner DT, Guarini CB, Khatri L, Goffer Y, Xu D, Titcombe RF, Khatri M, Marzan DS, Mahajan SS, Wang J, Froemke RC, et al. (2013) Sucrose ingestion induces rapid AMPA receptor trafficking. J Neurosci 33:6123-6132. CrossRef Medline

Ungless MA, Grace AA (2012) Are you or aren't you? Challenges associated with physiologically identifying dopamine neurons. Trends Neurosci 35: 422-430. CrossRef Medline

Valenza M, Steardo L, Cottone P, Sabino V (2015) Diet-induced obesity and diet-resistant rats: differences in the rewarding and anorectic effects of D-amphetamine. Psychopharmacology (Berl) 232:3215-3226. CrossRef Medline

van den Top M, Lee K, Whyment AD, Blanks AM, Spanswick D (2004) Orexigen-sensitive NPY/AGRP pacemaker neurons in the hypothalamic arcuate nucleus. Nat Neurosci 7:493-494. CrossRef Medline

van Zessen R, van der Plasse G, Adan RA (2012) Contribution of the mesolimbic dopamine system in mediating the effects of leptin and ghrelin on feeding. Proc Nutr Soc 71:435-445. CrossRef Medline

Vertes RP, Hoover WB (2008) Projections of the paraventricular and paratenial nuclei of the dorsal midline thalamus in the rat. J Comp Neurol 508:212-237. CrossRef Medline

Vollbrecht PJ, Mabrouk OS, Nelson AD, Kennedy RT, Ferrario CR (2016)
Pre-existing differences and diet-induced alterations in striatal dopamine systems of obesity-prone rats. Obesity (Silver Spring) 24:670-677. CrossRef Medline

Vong L, Ye C, Yang Z, Choi B, Chua S Jr, Lowell BB (2011) Leptin action on GABAergic neurons prevents obesity and reduces inhibitory tone to POMC neurons. Neuron 71:142-154. CrossRef Medline

Wang D, He X, Zhao Z, Feng Q, Lin R, Sun Y, Ding T, Xu F, Luo M, Zhan C (2015a) Whole-brain mapping of the direct inputs and axonal projections of POMC and AGRP neurons. Front Neuroanat 9:40. CrossRef Medline

Wang GJ, Volkow ND, Logan J, Pappas NR, Wong CT, Zhu W, Netusil N, Fowler JS (2001) Brain dopamine and obesity. Lancet 357:354-357. CrossRef Medline

Wang XF, Liu JJ, Xia J, Liu J, Mirabella V, Pang ZP (2015b) Endogenous glucagon-like peptide-1 suppresses high-fat food intake by reducing synaptic drive onto mesolimbic dopamine neurons. Cell Rep 12:726-733. CrossRef Medline

Watabe-Uchida M, Zhu L, Ogawa SK, Vamanrao A, Uchida N (2012) Whole-brain mapping of direct inputs to midbrain dopamine neurons. Neuron 74:858-873. CrossRef Medline

Watson C (2012) The mouse nervous system. San Diego: Academic.

Webber ES, Bonci A, Krashes MJ (2015) The elegance of energy balance: Insight from circuit-level manipulations. Synapse 69:461-474. CrossRef Medline

Weingarten HP (1983) Conditioned cues elicit feeding in sated rats: a role for learning in meal initiation. Science 220:431-433. CrossRef Medline

Williams KW, Margatho LO, Lee CE, Choi M, Lee S, Scott MM, Elias CF, Elmquist JK (2010) Segregation of acute leptin and insulin effects in distinct populations of arcuate proopiomelanocortin neurons. J Neurosci 30:2472-2479. CrossRef Medline

Wise RA (2006) Role of brain dopamine in food reward and reinforcement. Philos Trans R Soc Lond B Biol Sci 361:1149-1158. CrossRef Medline

Wolf ME (2016) Synaptic mechanisms underlying persistent cocaine craving. Nat Rev Neurosci 17:351-365. CrossRef Medline

Woods SC, Lotter EC, McKay LD, Porte D Jr (1979) Chronic intracerebroventricular infusion of insulin reduces food intake and body weight of baboons. Nature 282:503-505. CrossRef Medline

World Health Organisation (2016) Obesity and overweight factsheet. Available at: http://www.who.int/entity/mediacentre/factsheets/fs311/ en/index.html. Accessed July 5, 2016.

Yager LM, Garcia AF, Wunsch AM, Ferguson SM (2015) The ins and outs of the striatum: role in drug addiction. Neuroscience 301:529-541. CrossRef Medline

Yang Y, Atasoy D, Su HH, Sternson SM (2011) Hunger states switch a flipflop memory circuit via a synaptic AMPK-dependent positive feedback loop. Cell 146:992-1003. CrossRef Medline

Zhan C, Zhou J, Feng Q, Zhang JE, Lin S, Bao J, Wu P, Luo M (2013) Acute and long-term suppression of feeding behavior by POMC neurons in the brainstem and hypothalamus, respectively. J Neurosci 33:3624-3632. CrossRef Medline

Zhang M, Balmadrid C, Kelley AE (2003) Nucleus accumbens opioid, GABaergic, and dopaminergic modulation of palatable food motivation: contrasting effects revealed by a progressive ratio study in the rat. Behav Neurosci 117:202-211.

Zheng H, Lenard NR, Shin AC, Berthoud HR (2009) Appetite control and energy balance regulation in the modern world: reward-driven brain overrides repletion signals. Int J Obes (Lond) 33 [Suppl 2]:S8-S13.

Zigman JM, Jones JE, Lee CE, Saper CB, Elmquist JK (2006) Expression of ghrelin receptor mRNA in the rat and the mouse brain. J Comp Neurol 494:528-548. CrossRef Medline 